\title{
Nacellidae limpets of the southern end of South America: taxonomy and distribution
}

\author{
Lapas Nacellidae del extremo sur de Sudamérica: taxonomía y distribución
}

\author{
CLAUDIO VALDOVINOS* \& MAXIMILLIAN RÜTH
}

\author{
Unit of Aquatic Systems, EULA-Chile Environmental Sciences Centre, Universidad de Concepción and Patagonian \\ Ecosystems Research Center (CIEP) Casilla 160-C, Concepción, Chile; \\ *E-mail for correspondence: cvaldovi@udec.cl
}

\begin{abstract}
Taxonomically, the Mollusca of the southern end of South America are moderately well known, but the literature is scattered, there is little information on their habitats, and distributional records are scarce for the Chilean archipelago lying between Chiloé Island $\left(42^{\circ} \mathrm{S}\right)$ and Tierra del Fuego $\left(55^{\circ} \mathrm{S}\right)$. Although much is known about the biology and ecology of of some species of Nacellidae, the taxonomy of the group have been partially neglected, particularly in remote areas of the world such as the Chilean fjords. Therefore, this study aims to clarify the nomenclatural status, and establish the morphological characteristics and distribution of the Chilean Nacellidae. Especially, the following three objectives are pursued: (i) to clarify the correct identity of existing species; (ii) to describe of morphological details, highlighting the clear diagnostic characters of each species, and (iii) to delimitate and discuss their geographical range in Chile. The examination of the Nacellidae of the Chilean fiords has resulted in the recognition of one species of Nacella (Nacella) and seven species of Nacella (Patinigera), wherein the principal specific differences are in the shell (shape, thickness and color) and in radular teeth morphology. The genus Nacella and its subgenus Patinigera are cold-water limpets, and are exclusively inhabitants of Subantarctic and Antarctic waters. The greater part of their range being subantarctic, but extending to the Antarctic by way of the Scotia Arc, and also ranging northward up the Chilean coast to at least Valparaiso at $33^{\circ} \mathrm{S}$ (only $N$. (P.) clypeater). They apparently have their centre of distribution in the Magellanic Province of southern South America, corresponding to an area with a high degree of diversification $(N$. (N.) mytilina, $N$. (P.) chiloensis, $N$. (P.) deaurata, $N$. (P.) delicatissima, $N$. (P.) flammea, $N$. (P.) magellanica, $N$. (P.) venosa), wherefrom the species tends to spread eastward, with a larval transport probably assisted to a considerable extent by the prevailing West Wind Drift which strongly operates in the Subantarctic Zone.
\end{abstract}

Key words: Nacellidae, Nacella, Patinigera, Chile, taxonomy, distribution.

\section{RESUMEN}

Los moluscos del extremo sur de Sudamérica son desde un punto de vista taxonómico moderadamente bien conocidos. Sin embargo, la literatura está dispersa, hay poca información sobre sus hábitat y son muy pocos los registros distribucionales, particularmente en el área de los fiordos comprendidos entre la Isla de Chiloé $\left(42^{\circ} \mathrm{S}\right)$ y Tierra del Fuego $\left(55^{\circ} \mathrm{S}\right)$. Aunque se sabe bastante acerca de la biología y ecología de algunas especies de Nacellidae, la taxonomía del grupo ha sido relativamente poco estudiada, particularmente en áreas remotas del planeta, como es el caso de los fiordos chilenos. El interés del presente estudio ha sido clarificar el estatus nomenclatural y describir las características morfológicas y distribuciones de los Nacellidae chilenos. En particular, se plantearon los siguientes objetivos: (i) clarificar la identidad de las especies descritas, (ii) descripción de detalles morfológicos, destacando los caracteres diagnósticos de cada especie, y (iii) delimitación y discusión de sus rangos geográficos. El análisis de los Nacellidae de los fiordos chilenos ha permitido el reconocimiento de una especie de Nacella (Nacella) y siete de $N$. (Patinigera), cuyas principales diferencias a nivel de especie radican en la concha (forma, espesor y color) y en la morfología de la dentición radular. El género Nacella y su subgénero Patinigera son habitantes exclusivos de aguas antárticas y subantárticas. Estos organismos son lapas de aguas frías fundamentalmente subantárticas, pero que también se extienden hacia la Antártica por el área del Arco de Escocia, y hacia el norte a lo largo de la costa chilena, hasta el área de Valparaíso a $33^{\circ} \mathrm{S}(N$. (P.) clypeater). Aparentemente este género tiene su centro de distribución en la Provincia magallánica en el sur de Sudamérica, correspondiendo a un área de elevada diversidad de especies $(N$. $(N$.) mytilina, $N$. (P.) chiloensis, $N$. (P.) deaurata, $N$. (P.) delicatissima, $N$. (P.) flammea, $N$. (P.) magellanica, $N$. (P.) venosa), donde las especies tienden a dispersarse hacia el este, con un transporte larval probablemente facilitado por la corriente de deriva del oeste que opera fuertemente en la zona subantártica.

Palabras clave: Nacellidae, Nacella, Patinigera, Chile, taxonomía, distribución. 


\section{INTRODUCTION}

Although much is known about the biology and ecology of some species of Nacellidae (e.g., Nacella concinna Strebel, 1908; see StanwellSmith \& Clarke 1998, Morriconi 1999, Peck \& Veal 2001, Powell et al. 2001, Mahon et al. 2002), the taxonomy of the group have been partially neglected, particularly in remote areas of the world as the Chilean fjords in the southern end of South America (see Reid \& Osorio 2000:118). The most important taxonomic review of this taxonomic group was published by Powell (1973). However, many of the Nacellidae species of the Chilean coast remain difficult to be determined with accuracy, mainly because they were based on gross shell morphology, and because many of the distributional ranges of the species described for Chile are approximations, and based only on a few collection points. In addition, nothing is recorded regarding the anatomy of the Chilean species.

Historically, the external form of the shell was the principal character used in the specieslevel taxonomy of Patellogastropoda, but in many species this is highly variable, leading to taxonomic confusion (Sasaki \& Okutani 1993a, Ridgway et al. 1998). It has long been recognized that the radula is also a useful character for discrimination between species (Fischer-Piette 1935, Ridgway et al. 1998). The two most recent worldwide taxonomic monographs, by Powell (1973) and Christiaens (1973, 1974a, 1974b), both used a combination of shell morphology and radular characters in their diagnoses, but nevertheless show numerous disagreements. Other characters that have also been successfully used to discriminate between species include coloration of the foot and pallial tentacles (Bowman 1981, Cretella et al. 1990), sperm ultrastructure (Hodgson \& Bernard 1989), configuration of the loops of the gut (Ridgway et al. 1998), chromosome number (Cervella et al. 1988) and allozymes (Corte-Real et al. 1996).

In the older classifications the patellogastropods were divided into three families: (a) Lepetidae (gills absent; fused central tooth), (b) Acmaeidae (single ctenidial gill; with or without pallial gills; two pairs of lateral teeth; marginal teeth reduced or absent) and (c) Patellidae (ctenidial gill absent; pallial gills present; two or three pairs of lateral teeth; two or three pairs of marginal teeth) (Dall 1871, Pilsbry 1891, Thiele 1929, Wenz 1938, Keen 1960, Powell 1973). Within Patellidae as thus defined, two sub-families were generally recognized: (a) Patellinae (three pairs of lateral teeth) and (b) Nacellinae (two pairs of lateral teeth) (Thiele 1929, Wenz 1938, Keen 1960, Powell 1973). On the basis of unspecified shell and anatomical differences, the Nacellidae were raised to a family rank by Golikov \& Starobogatov (1975). Lindberg (1988), in his review of relationships in the Patellogastropoda, proposed a new division into two sub-orders: Patellina and Nacellina. The former contained the single family Patellidae, and was characterized by the presence of calcitic crossedfoliated outer shell layers. Its sister taxon, Nacellina, has been defined by a chromosomal character, characters of the salivary glands, oesophagus and nervous system, and by a reduction of the number of radular teeth (Lindberg 1988, 1998, Lindberg \& Hedergaard 1996). According to Lindberg (1988), the suborder Nacellina comprises four families, i.e., Nacellidae, Lepetidae, Acmaeidae and Lotiidae. The present study uses Nacellidae in the sense of Lindberg (1988), although the affinities of Nacellidae (including Nacella and Cellana) with the other families remain controversial (Ridgway et al. 1998).

This study aims to clarify the nomenclatural status, and establish the morphological characteristics and distributions of Nacellidae of the Chilean fiords. In particular, the following three objectives are pursued: (i) to clarify the correct identity of existing species; (ii) to describe of morphological details, highlighting clear diagnostic characters of each species, and (iii) to delimitate and discuss their geographical range in Chile.

\section{MATERIAL AND METHODS}

Most of the material from the Chilean Fiords used in this study was obtained from the Zoological Museum of the University of Concepción, Chile (Universidad de Concepción, Colecciones Científicas, UCCC). The material from the Chilean-Peruvian Province, was taken alive from 13 sites between 1998-2000. In addition, dried shell specimens of private 
collections were examined for geographic distribution data. The taxonomic terminology in this paper was mainly adopted from Lindberg (1981) and Lindberg \& McLean (1981), and partly Fretter \& Graham (1962), Walker (1968), and Ponder \& Creece (1980) (for radula terminology see Fig. 3F).

Specimens were fixed in $70 \%$ alcohol directly or sometimes after settling in solution of magnesium chloride either in seawater or frozen to preserve a live body color. In fresh specimens, the external anatomy and color of the body were observed. Pigmentation of the head, cephalic tentacles, sides of the foot, and mantle margin, could be observed even in fixed specimens, so that the dark pigments of these portions did not fade in the preservative. After the configuration of the radular sac and digestive tract were traced by dissection, the radula was removed under a binocular microscope. Extracted radulae were soaked in $50 \% \mathrm{KOH}$ solution at approximately $40^{\circ} \mathrm{C}$ for about $5 \mathrm{~min}$, rinsed in distilled water, and then cleaned with ultrasonic cleaner. Radulae and shell sculpture in young specimens barely affected by erosion, were observed through SEM using a Autoscan U1, Siemens ETEC microscope, in the Laboratory of the University of Concepcion. Measurements of the shells were made using a vernier ( $0.5 \mathrm{~mm}$ sensibility) and with a graduate ocular. The weight of the shells was measured with a Precisa 240A digital balance. For each species the Length/ Height Index and Length/Weight Index, were calculated based on the average of all the measurements.

Species were compared to define groups with similar shell morphology. A species matrix of shell characters were analyzed through nonmetric multidimensional (NMDS) ordination (Field et al. 1982), using a Bray-Curtis dissimilarity matrix (Bray \& Curtis 1957). A multivariate analysis of variance (MANOVA) was used to establish the statistical significance of differences in shell morphometry among species. Prior to the comparison of species, data were transformed using the $\log _{10}(x+1)$ function to reduce the bias of very large structures and to give more weight to small structures. The shell characters studied by ordination and MANOVA (values standardized by length of the shell) were the following: shell width, height, apex-anterior and weight.

\section{RESULTS}

Family Nacellidae Thiele, 1891; genus Nacella Schumacher, 1817; subgenus Nacella Schumacher, 1817; type: Patella mytilina Helbling, 1779.

(1) Nacella (Nacella) mytilina (Helbling, 1779) (Fig. 1, 2A, 3A, 4A; Table 1)

Synonymy: Patella mytilina Helbling, 1779: Vol. 4: 104, pl. 1, Figs. 5, 6; Gmelin, 1791:3698; Strebel, 1907:113, pl. 3, Fig. 44; pl. 4, Figs. 49, 51, 55, 57A, 59. - Patella mytiliformis Lightfoot, 1786: 42. - Patella conchacea Gmelin, 1791: 3708. - Nacella mytiloides Schumacher, 1817: 179. - Patella cymbularia Lamarck, 1819: Vol. 6: 335; Mermod, 1950: 700, Fig. 11. - Patella cymbuloides Lesson, 1831: 422. - Patella hyalina Philippi, 1845: Vol. 11: 59. - Patella vitrea Philippi, 1845: Vol. 11: 60. - Patella cymbium Philippi, 1845; Vol. 11: 60. - Nacella mytilina Dall, 1870: 274; Rochebrune \& Mabille, 1889: 97; Pilsbry, 1891: 115, pl. 50, Figs. 32-39; Pelseneer, 1903: 6; Smith, 1905: 336; Thiele, 1912: 234; Melvill \& Standen, 1914: 114; Carcelles, 1950: Vol. 2: 52; Powell, 1951: Vol. 26: 80; Dell, 1964: 273; 1971: 201; Powell, 1973: Vol. 3, 191, pl. 173, Figs. 1, 2. Nacella compressa Rochebrune \& Mabille, 1889: Vol. 6: 98, pl. 5, Fig. 9. - Nacella falklandica Preston, 1913: Vol. 11: 221, pl. 4, Fig. 6. - Nacella (Nacella) mytilina Wenz, 1938: 217, Fig. 400; Carcelles \& Williamson, 1951: 257; Carcelles, 1953: 164, pl. 1, Fig. 11; Ramírez, 1985: 51.

Material studied: Isla Dawson in Puerto Harris $\left(53^{\circ} 55^{\prime} \mathrm{S} ; 70^{\circ} 45^{\prime} \mathrm{W}\right): \mathrm{n}=1$ UCCC: 10356. Isla Guarello $\left(50^{\circ} 23^{\prime} \mathrm{S} ; 75^{\circ} 20^{\prime} \mathrm{W}\right): \mathrm{n}=$ 11 UCCC:1357. Near Isla Guarello (50 $23^{\prime} \mathrm{S}$; $\left.75^{\circ} 25^{\prime} \mathrm{W}\right): \mathrm{n}=4 \mathrm{UCCC}: 15493$. Punta Arenas $\left(53^{\circ} 09^{\prime} \mathrm{S} ; 70^{\circ} 55^{\prime} \mathrm{W}\right): \mathrm{n}=2$ UCCC: $2544 ; \mathrm{n}=$ 3 UCCC: 10235; $\mathrm{n}=5$ UCCC: 10234; $\mathrm{n}=4$

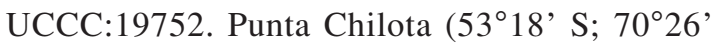
W) $: \mathrm{n}=1$ UCCC: $106 ; \mathrm{n}=1$ UCCC: 1045 . Tres Puentes $\left(53^{\circ} 07^{\prime} \mathrm{S} ; 70^{\circ} 53^{\prime} \mathrm{W}\right): \mathrm{n}=1$ UCCC:2543.

Description: shell (Fig. 1, 2A, Table 1): conical form, oblique, very thin, translucent, laterally compressed. Large (maximum length $53 \mathrm{~mm}$ ), profile of medium height (Length/ Height Index $=2.62$; Length/Weight Index $=$ 26.78). Apex situated at anterior $5 \%$ of the 
shell's length, anteriorly directed and curved towards the border, obtuse. Anterior slope concave, posterior and lateral slopes convex. Aperture oval-oblong. Sculpture of few and moderate radial ribs, more obvious in the anterior zone. Presence of concentric growthlines that increase in thickness towards the margin. Shell margin relatively even, ribs project slightly. Exterior coloration pearly cream, with darker tones towards the margin. Interior simple, with white nacreous coloration.

The non-metric multidimensional scaling (NMDS) ordination based on the measures of the shells, shows that N.(N.) mytilina presents a low degree of similarity with $N$. $(P$.) delicatissima (Fig. 7), but being clearly different of the other species of Nacella. However, the multivariate analysis of variance (MANOVA), shows that N.(N.) mytilina and $N$. (P.) delicatissima presents statistically significant differences among them (Table 2).
Radula (Fig. 1, 3A, 4A): the innermost lateral teeth (Ilt) are closely set at the anterior edge of ribbon segment, arranged in a parallel configuration and shovel-like shape in lateral view. $\mathrm{C} 1$ is wide, pointed; medial edge divided into two straight segments, lateral edge convex. $\mathrm{C} 2$ is short and thin, blunt; medial edge slightly concave, lateral edge convex. The middle lateral tooth (Mlt) is posterior and lateral to the innermost tooth. It is broad and wider than the innermost, and shovel-like shape in lateral view. $\mathrm{C} 1$ is very reduced in size, thin, sharply pointed; medial edge convex, lateral edge straight. C2 is short, broad, pointed and laterally directed; medial edge divided into two segments, a straight one, and one slightly convex, lateral edge slightly convex (Length Mlt/Wide Mlt Index = 1.42). The outermost lateral tooth $(\mathrm{Olt})$ is broad and laterally situated towards the middle tooth. The cusp is triangular in lateral view, pointed; medial and lateral edges straight.

\begin{tabular}{|c|c|c|c|c|c|c|c|c|}
\hline & Nacella & \multicolumn{7}{|c|}{ Nacella (Patinigera) } \\
\hline & mytilina & clypeater & chiloensis & deaurata & delicatissima & magellanica & venosa & flammea \\
\hline \multicolumn{9}{|l|}{$\begin{array}{c}\text { Shell } \\
\text { sculpture }\end{array}$} \\
\hline $\begin{array}{l}\text { Mantle } \\
\text { tentacles }\end{array}$ & & & & & & & & ? \\
\hline Radula & & & & & & & & ? \\
\hline Radula & & & & & & & & ? \\
\hline Pigmentation & & & & & & & & $?$ \\
\hline & & & & & & & & \\
\hline
\end{tabular}

Fig. 1: Comparison of five major specific characters of the Chilean species of Nacella.

Comparación de los cinco principales caracteres específicos de las especies chilenas de Nacella. 
TABLE 1

Size and weight measurements of the shell of the Chilean species of Nacella

Talla y peso de conchas de las especies chilenas de Nacella

\begin{tabular}{|c|c|c|c|c|c|c|}
\hline Species & & $\begin{array}{l}\text { Length } \\
(\mathrm{mm})\end{array}$ & $\begin{array}{l}\text { Width } \\
(\mathrm{mm})\end{array}$ & $\begin{array}{l}\text { Height } \\
(\mathrm{mm})\end{array}$ & $\begin{array}{l}\text { Apex- } \\
\text { anterior } \\
(\mathrm{mm})\end{array}$ & $\begin{array}{l}\text { Weight } \\
\text { (g) }\end{array}$ \\
\hline $\begin{array}{l}\text { Nacella (Nacella) mytilina } \\
(\text { Helbling, 1779) } \\
(\mathrm{n}=33)\end{array}$ & $\begin{array}{l}\text { Mean } \\
\text { SD } \\
\text { Min } \\
\text { Max }\end{array}$ & $\begin{array}{r}39.1 \\
6.0 \\
33.0 \\
53.0\end{array}$ & $\begin{array}{r}24.2 \\
3.8 \\
21.0 \\
33.0\end{array}$ & $\begin{array}{r}14.9 \\
3.2 \\
11.0 \\
22.0\end{array}$ & $\begin{array}{l}2.3 \\
1.9 \\
0.0 \\
6.0\end{array}$ & $\begin{array}{l}1.46 \\
0.80 \\
0.74 \\
3.40\end{array}$ \\
\hline $\begin{array}{l}\text { Nacella (Patinigera) chiloensis } \\
\text { (Reeve, 1855) } \\
(\mathrm{n}=61)\end{array}$ & $\begin{array}{l}\text { Mean } \\
\text { SD } \\
\text { Min } \\
\text { Max }\end{array}$ & $\begin{array}{r}34.5 \\
3.8 \\
28.0 \\
36.0\end{array}$ & $\begin{array}{r}32.5 \\
3.2 \\
28.0 \\
33.0\end{array}$ & $\begin{array}{r}15.2 \\
2.8 \\
12.0 \\
20.0\end{array}$ & $\begin{array}{r}14.3 \\
2.3 \\
11.0 \\
17.0\end{array}$ & $\begin{array}{l}3.00 \\
1.60 \\
0.21 \\
5.71\end{array}$ \\
\hline $\begin{array}{l}\text { Nacella (Patinigera) clypeater } \\
(\text { Lesson, 1831) } \\
(\mathrm{n}=35)\end{array}$ & $\begin{array}{l}\text { Mean } \\
\text { SD } \\
\text { Min } \\
\text { Max }\end{array}$ & $\begin{array}{r}33.6 \\
4.4 \\
27.5 \\
39.0\end{array}$ & $\begin{array}{r}30.3 \\
3.7 \\
26.0 \\
36.0\end{array}$ & $\begin{array}{l}7.1 \\
1.0 \\
5.5 \\
8.5\end{array}$ & $\begin{array}{r}13.2 \\
2.6 \\
10.0 \\
18.0\end{array}$ & $\begin{array}{l}1.52 \\
0.69 \\
0.80 \\
2.39\end{array}$ \\
\hline $\begin{array}{l}\text { Nacella (Patinigera) deaurata } \\
(\text { Gmelin, 1791) } \\
(\mathrm{n}=71)\end{array}$ & $\begin{array}{l}\text { Mean } \\
\text { SD } \\
\text { Min } \\
\text { Max }\end{array}$ & $\begin{array}{r}36.3 \\
8.5 \\
26.0 \\
55.0\end{array}$ & $\begin{array}{r}25.9 \\
6.8 \\
18.0 \\
41.0\end{array}$ & $\begin{array}{r}11.2 \\
4.5 \\
7.0 \\
20.0\end{array}$ & $\begin{array}{r}7.6 \\
3.4 \\
4.0 \\
13.0\end{array}$ & $\begin{array}{l}2.00 \\
1.91 \\
0.47 \\
6.09\end{array}$ \\
\hline $\begin{array}{l}\text { Nacella (Patinigera) delicatissima } \\
(\text { Strebel, 1907) } \\
(\mathrm{n}=16)\end{array}$ & $\begin{array}{l}\text { Mean } \\
\text { SD } \\
\text { Min } \\
\text { Max }\end{array}$ & $\begin{array}{r}29.1 \\
4.2 \\
21.0 \\
37.0\end{array}$ & $\begin{array}{r}20.4 \\
3.6 \\
14.0 \\
27.0\end{array}$ & $\begin{array}{r}8.6 \\
2.4 \\
6.0 \\
14.0\end{array}$ & $\begin{array}{r}5.5 \\
2.0 \\
4.0 \\
10.0\end{array}$ & $\begin{array}{l}1.03 \\
0.78 \\
0.31 \\
3.05\end{array}$ \\
\hline $\begin{array}{l}\text { Nacella (Patinigera) flammea } \\
(\text { Gmelin, 1791) } \\
(\mathrm{n}=3)\end{array}$ & $\begin{array}{l}\text { Mean } \\
\text { SD } \\
\text { Min } \\
\text { Max }\end{array}$ & $\begin{array}{l}26.5 \\
17.7 \\
14.0 \\
39.0\end{array}$ & $\begin{array}{l}19.0 \\
12.7 \\
10.0 \\
28.0\end{array}$ & $\begin{array}{l}5.8 \\
3.9 \\
3.0 \\
8.5\end{array}$ & $\begin{array}{r}10.8 \\
6.7 \\
6.0 \\
15.5\end{array}$ & $\begin{array}{l}0.59 \\
0.76 \\
0.05 \\
1.12\end{array}$ \\
\hline $\begin{array}{l}\text { Nacella (Patinigera) magellanica } \\
(\text { Gmelin, 1791) } \\
(\mathrm{n}=111)\end{array}$ & $\begin{array}{l}\text { Mean } \\
\text { SD } \\
\text { Min } \\
\text { Max }\end{array}$ & $\begin{array}{r}42.5 \\
3.7 \\
34.5 \\
62.5\end{array}$ & $\begin{array}{r}36.4 \\
3.1 \\
29.5 \\
55.0\end{array}$ & $\begin{array}{r}22.6 \\
3.5 \\
18.0 \\
44.5\end{array}$ & $\begin{array}{r}18.1 \\
2.3 \\
15.0 \\
40.0\end{array}$ & $\begin{array}{r}8.00 \\
2.80 \\
4.25 \\
16.69\end{array}$ \\
\hline $\begin{array}{l}\text { Nacella (Patinigera) venosa } \\
\text { (Reeve, 1854) } \\
(\mathrm{n}=42)\end{array}$ & $\begin{array}{l}\text { Mean } \\
\text { SD } \\
\text { Min } \\
\text { Max }\end{array}$ & $\begin{array}{r}30.8 \\
2.3 \\
28.0 \\
35.0\end{array}$ & $\begin{array}{r}27.8 \\
1.8 \\
25.0 \\
31.0\end{array}$ & $\begin{array}{r}13.4 \\
1.6 \\
11.0 \\
16.0\end{array}$ & $\begin{array}{r}12.5 \\
1.6 \\
10.0 \\
15.0\end{array}$ & $\begin{array}{l}2.30 \\
0.50 \\
1.58 \\
3.05\end{array}$ \\
\hline
\end{tabular}

Radular sac (Fig. 1): The radular sac is medium in length. It extends backwards towards the anterior third of the visceral cavity and curves to the left margin in a sigmoid form, turning into two loops in the left anterior part of the visceral mass, between the gonad and the digestive tract (Length Shell/Length Radula Index $=2.34$ ).

External anatomy (Fig. 1): The ventral area of the foot is dark greenish gray to the vicinity of the epipodial fringe. The mantle fold is medium in thickness and cream colored. The mantle tentacles are in series, which are alternated, three white shorter ones and a black and long one. The cephalic tentacles are dorsally pigmented with black.

Distribution: Magellanic Province, from Guarello Island through Straits of Magellan (type locality) and Cape Horn in Chile, and Patagonia (mouth of Santa Cruz River); Falkland Island; Kerguelen Island (Swain's Bay and Antares Island, sensu Powell, 1973). Depth range: 0-30 $\mathrm{m}$. 
Subgenus Patinigera Dall, 1905; Type: Patella magellanica Gmelin, 1791

(2) Nacella (Patinigera) chiloensis (Reeve, 1855) (Fig. 1, 2B, 3C, 4C; Table 1)

Synonymy: Patella chiloensis Reeve, 1855: pl. 33, Figs. 98A,B. - Patinella chiloensis Strebel,
1907: 151, pl. 7, Figs. 89, 90. - Patinigera chiloensis Dell, 1964: 273. - Patella chiloensis Powell, 1973: 198, pl. 180, Figs. 3, 4 (figures of the Pl. 180 from Powell, have an error in their numeration, in relation with those of Reeve. The correct numbers for chiloensis form are 1, 2). - Nacella (Patinigera) magellanica subspecies chiloensis Ramírez, 1985: 55.
(A)
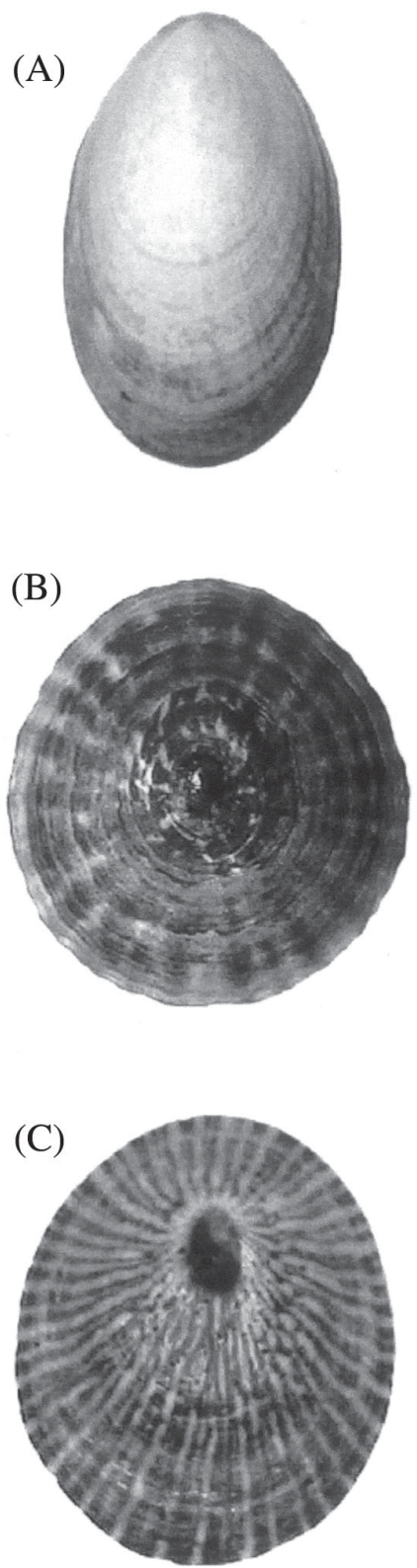
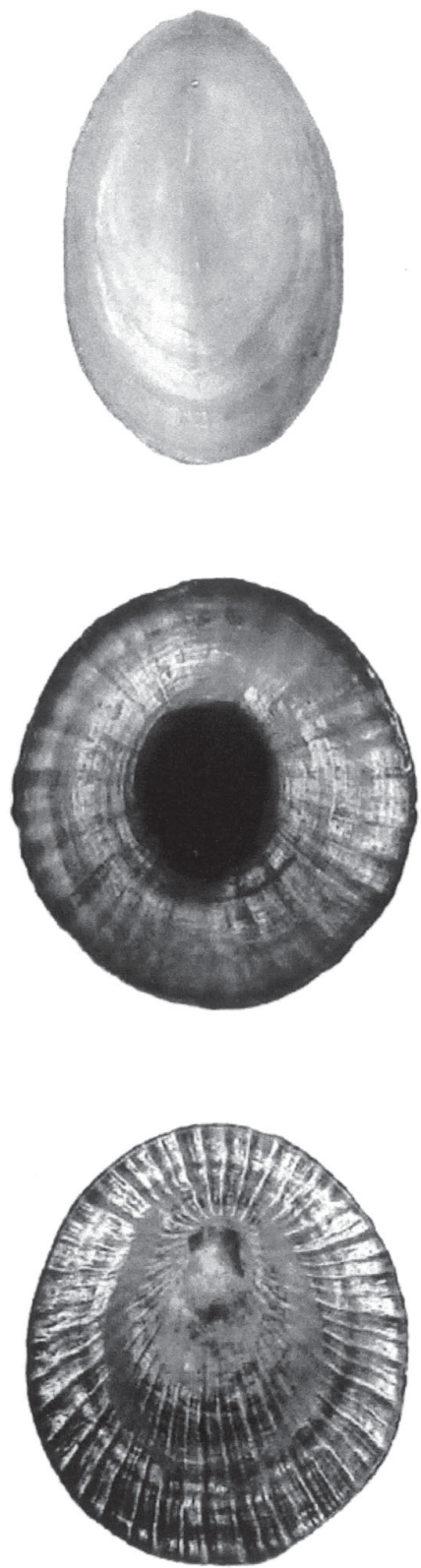
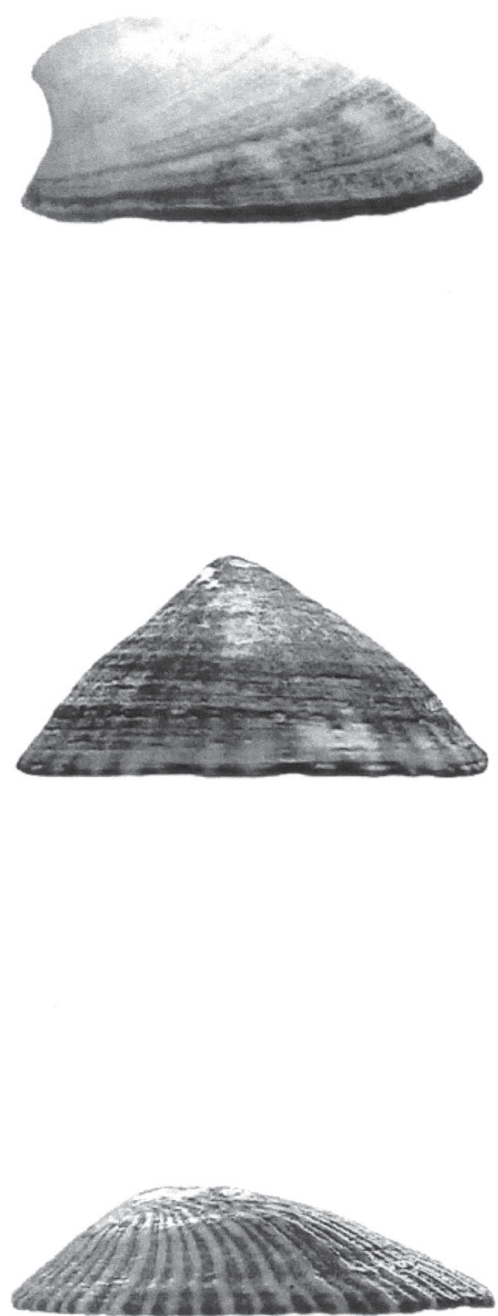

Fig. 2: Shells (dorsal, ventral and lateral views). (A) Nacella (Nacella) mytilina (length $53 \mathrm{~mm}$; UCCC: 1045); (B) N. (P.) chiloensis (length $36 \mathrm{~mm}$; UCCC: 6578); (C) N. (Patinigera) clypeater (length $39 \mathrm{~mm}$; UCCC: 2512).

Conchas (vistas dorsal, ventral y lateral). (A) Nacella (Nacella) mytilina (largo $53 \mathrm{~mm}$; UCCC: 1045); (B) N. (P.) chiloensis (largo 36 mm; UCCC: 6578); (C) N. (Patinigera) clypeater (largo $39 \mathrm{~mm}$; UCCC: 2512). 

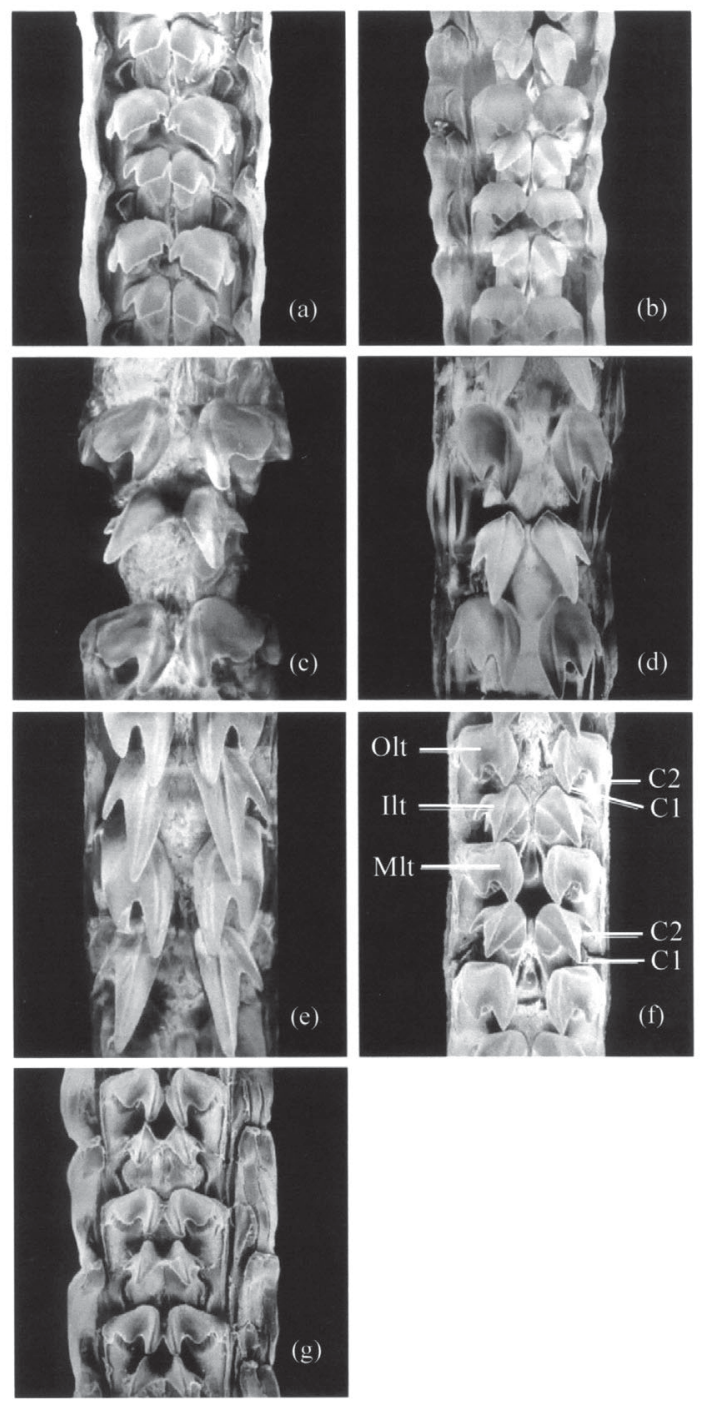

Fig. 3: Scanning electron micrographs of the radula (frontal view, x 130). (A) Nacella (Nacella) mytilina (UCCC: 1045); (B) N. (Patinigera) clypeater (UCCC: 2512); (C) N. (P.) chiloensis (UCCC: 6578); (D) N. (P.) deaurata (UCCC: 1043); (E) N. (P.) delicatissima (UCCC: 2345); (F) N. (P.) magellanica (UCCC: 2391); (G) N. (P.) venosa (UCCC: 5723 ). $\mathrm{C} 1=$ Cuspid 1, C2 = Cuspid 2, Il $\mathrm{t}=$ Innermost lateral tooth, Mlt $=$ Middle lateral tooth, $\mathrm{Olt}=$ Outermost lateral tooth.

Fotografías de la rádula obtenidas con microscopio electrónico de barrido (vista frontal, x 130). (A) Nacella (Nacella) mytilina (UCCC: 1045); (B) N. (Patinigera) clypeater (UCCC: 2512); (C) N. (P.) chiloensis (UCCC: 6578); (D) N. (P.) deaurata (UCCC: 1043); (E) N. (P.) delicatissima (UCCC: 2345); (F) N. (P.) magellanica (UCCC: 2391); (G) N. (P.) venosa (UCCC: 5723). C1 = Cúspide 1 , $\mathrm{C} 2=$ Cúspide $2, \mathrm{Ilt}=$ Diente lateral interno, $\mathrm{Mlt}=$ Diente lateral medio, Olt $=$ Diente lateral externo
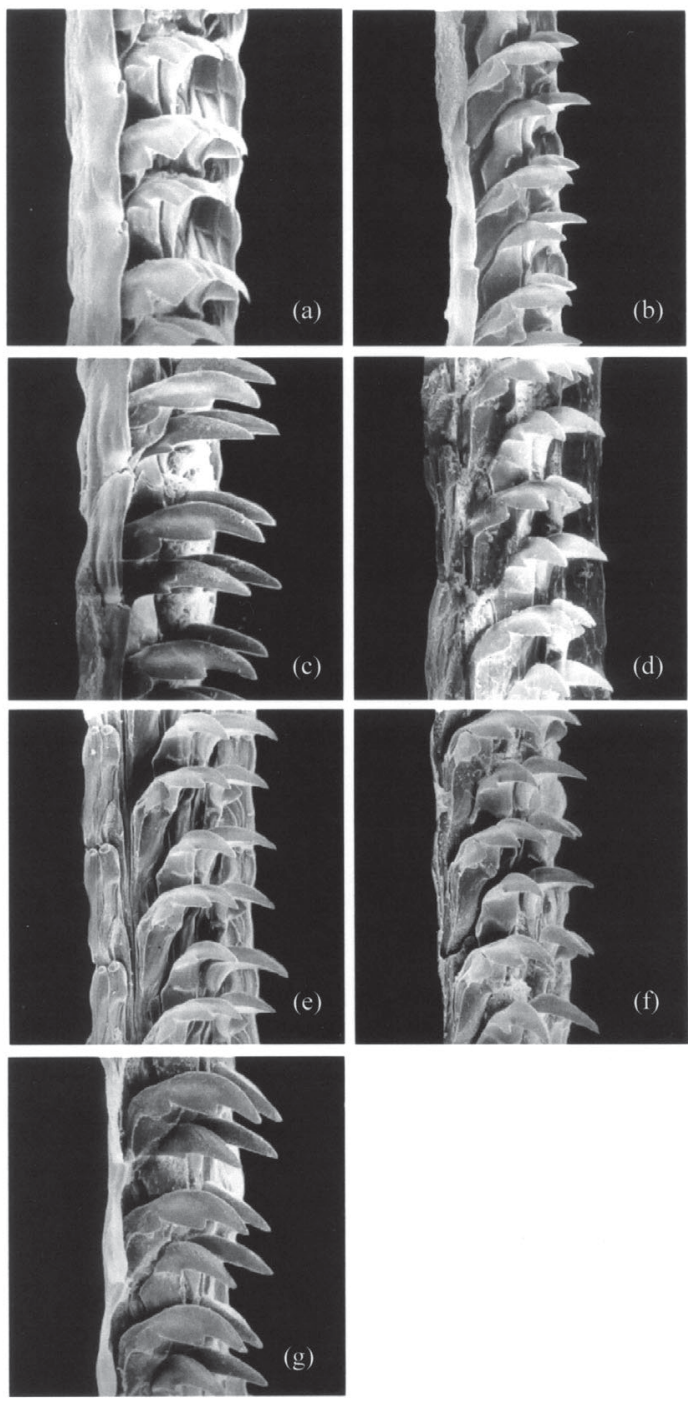

Fig. 4: Scanning electron micrographs of the radula (lateral view, x 130). (A) Nacella (Nacella) mytilina (UCCC: 1045); (B) N. (Patinigera) clypeater (UCCC: 2512); (C) N. (P.) chiloensis (UCCC: 6578); (D) N. (P.) deaurata (UCCC: 1043); (E) N. (P.) delicatissima (UCCC: 2345); (F) N. (P.) magellanica (UCCC: 2391); (G) N. (P.) venosa (UCCC: 5723).

Fotografías de la rádula obtenidas con microscopio electrónico de barrido (vista lateral, x 130). (A) Nacella ( $\mathrm{Na}$ cella) mytilina (UCCC: 1045); (B) N. (Patinigera) clypeater (UCCC: 2512); (C) N. (P.) chiloensis (UCCC: 6578); (D) N. (P.) deaurata (UCCC: 1043); (E) N. (P.) delicatissima (UCCC: 2345); (F) N. (P.) magellanica (UCCC: 2391); (G) N. (P.) venosa (UCCC: 5723). 
Material studied: Isla Talcán $\left(42^{\circ} 45^{\prime} \mathrm{S}\right.$; $\left.72^{\circ} 50^{\prime} \mathrm{W}\right): \mathrm{n}=2$ UCCC 1245 . Pargua $\left(41^{\circ} 47^{\prime}\right.$ $\left.\mathrm{S} ; 7^{\circ} 25^{\prime} \mathrm{W}\right): \mathrm{n}=19$ UCCC: $6578 ; \mathrm{n}=15$ UCCC: 5754. Pumalín - Chiloé Island (42 $41^{\prime}$ 'S; 7249' W): $\mathrm{n}=25$ UCCC: 15487 .

Description: shell (Fig. 1, 2B; Table 1): conical form, thick, not translucent, laterally compressed in the anterior zone. Small size (maximum length $36 \mathrm{~mm}$ ), medium height profile (Length/Height Index $=2.27$; Length/ Weight Index $=11.50$ ). Sharp pointed apex, situated at anterior $40 \%$ of the shell's length. All slopes slightly convex. Aperture suboval. Sculpture of low rounded primary radial ribs, secondary ribs arising in the interspaces, not reaching thickness of primary ribs. Concentric growth-lines prominent through out. Primary ribs dark brown to black, interspaces in a more clear tone follow the coloration pattern. Exterior color pattern concentric, apical zone dark gray with dun brown spotted umbo; central zone gray-blue with soft radial dark rays: marginal zone dark gray. Shell margin relatively even, ribs project slightly. Soft nacreous interior with a blue-plated halo. Dun brown spot in the interior corresponding to animal body impression. Brown colored thin radial rays, with clear interspaces. Dark coloration towards the marginal zone.

The non-metric multidimensional scaling (NMDS) ordination based on the measures of the shells, shows that $N$.(P.) chiloensis presents a degree of similarity with $N$. (P.) magellanica and $N$. (P.) venosa (Fig. 7), but being clearly different of the other species of Nacella. The multivariate analysis of variance (MANOVA), shows that $N$. (P.) chiloensis and N. (P.) delicatissima presents statistically significant differences among them (Table 2), but not with $N$. (P.) venosa. However, the clear differences in shell pigmentation and other characters (see below), permit the clear recognition of the species.

Radula (Fig. 1, 3C, 4C): the innermost lateral teeth are closely set at the anterior edge of ribbon segment, arranged in a posteriorly diverging $\mathrm{V}$-configuration and slightly curved backwards $\mathrm{C} 1$ is long, pointed, with a straight broad ridge running from the middle of the base towards the posterior tip of the tooth; medial edge straight, lateral edge concave. C2 is short, blunt, and laterally directed; medial edge straight, lateral edge sigmoid. The middle lateral tooth is posterior and lateral to the innermost tooth, and it has curved posteriorlylaterally and backwardly. $\mathrm{C} 1$ is the largest of all three teeth, pointed, with a curved ridge from the outer anterior corner of the base towards the posterior tip of the tooth; medial edge convex, lateral edge slightly concave. C2 is short and wider than $\mathrm{C} 1$; medial and lateral edges slightly convex (Length Mlt/Wide Mlt Index $=1.62$ ). The outermost lateral tooth is laterally situated to the middle tooth. The cusp is blunt; medial and lateral edges convex.

Radular sac (Fig. 1): the radular sac is long. It extends backwards towards the middle of the visceral cavity coiling in three ventrally directed loops in the left anterior part of the visceral mass, between the gonad and the digestive tract. The third loop is projected to the anterior right margin, overlapping the first and second loops in the anterior zone (Length Shell/Length Radula Index $=2.15$ ).

External anatomy (Fig. 1): the ventral area of the foot is dark greenish gray. The mantle fold is thick and dun brown colored, bordered by a black narrow line. The mantle tentacles are in series, which are alternated by one longer dark gray, a white little one and one short and white. The cephalic tentacles are dorsally pigmented in black.

Distribution: Chiloé Island and Pargua. Depth range: 0-30 m.

(3) Nacella (Patinigera) clypeater (Lesson, 1831) (Fig. 1, 2C, 3B, 4B; Table 1)

Synonymy: Patella clypeater Lesson, 1831: 419; Reeve, 1854: pl. 16, Figs. A, B.; Huppé, 1854: 259. - Nacella (Patinella) clypeater Pilsbry, 1891: 122, pl. 50, Figs. 40, 43. Patinigera clypeata Dell, 1964: 273. - Nacella (Patinigera) clypeater Powell, 1973: 193, pl. 175, Figs. 1, 2; Ramírez, 1985: 52.

Material studied: Playa Constitución Maule $\left(35^{\circ} 32^{\prime} \mathrm{S} ; 71^{\circ} 42^{\prime} \mathrm{W}\right): \mathrm{n}=2$ UCCC: 165. Punta Águila - Arauco ( $37^{\circ} 13^{\prime} \mathrm{S} ; 7^{\circ} 28^{\prime}$ $\mathrm{W}): \mathrm{n}=5$ UCCC: 2512 . Maullín (41 $37^{\circ} \mathrm{S}$; $\left.73^{\circ} 37^{\prime} \mathrm{W}\right): \mathrm{n}=1$ UCCC 18566. Bahía Mansa (403' S; 7346' W): n = 2 UCCC 18567. Pucatrihue $\left(40^{\circ} 26^{\prime} \mathrm{S} ; 7^{\circ} 47^{\prime} \mathrm{W}\right): \mathrm{n}=1 \mathrm{UCCC}$ 18568. Maicolpué $\left(40^{\circ} 30^{\prime} \mathrm{S} ; 73^{\circ} 45^{\prime} \mathrm{W}\right): \mathrm{n}=5$ UCCC 18569. Hueicolla $\left(40^{\circ} 08^{\prime}\right.$ S; $73^{\circ} 42^{\prime}$ W): $\mathrm{n}=12$ UCCC 18570. Puerto Saavedra (38 $46^{\circ}$ 
$\left.\mathrm{S} ; 7^{\circ} 26^{\prime} \mathrm{W}\right): \mathrm{n}=1 \mathrm{UCCC}$ 18571. Lebu

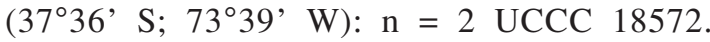
Punta Lavapié $\left(37^{\circ} 08^{\prime} \mathrm{S} ; 73^{\circ} 34^{\prime} \mathrm{W}\right): \mathrm{n}=10$ UCCC 18573. Ramuntcho ( $36^{\circ} 45^{\prime} \mathrm{S} ; 7^{\circ} 20^{\prime}$ $\mathrm{W}): \mathrm{n}=8$ UCCC 18574. Bahía de Coliumo $\left(36^{\circ} 33^{\prime} \mathrm{S} ; 72^{\circ} 58^{\prime} \mathrm{W}\right): \mathrm{n}=1$ UCCC 18575. Valparaíso $\left(33^{\circ} 30^{\prime} \mathrm{S} ; 71^{\circ} 38^{\prime} \mathrm{W}\right): \mathrm{n}=2 \mathrm{UCCC}$ 18576.

Description: shell (Fig. 1, 2C; Table 1): conical form, thin, relatively translucent, depressed. Medium size (maximum length 39 $\mathrm{mm}$ ), profile of very low height (Length/Height Index $=4.73$; Length/Weight Index $=22.10$ ). Apex situated at anterior $30 \%$ of the shell's length, obtuse. Anterior slope straight, the posterior and lateral slopes are slightly convex. Aperture oval. Sculpture of fine rounded near radial ribs, beginning below apex. Presence of concentric growth lines notorious below the apex. Shell margin relatively even. Exterior coloration with cream ribs and dun-brown interspaces. Interior silvery to pale bronze, with a dun-brown spot corresponding to the animal's body impression.

The non-metric multidimensional scaling (NMDS) ordination and the multivariate analysis of variance (MANOVA), based on the measures of the shells, shows that $N$. (N.) clypeater is clearly different of the other species of Nacella. (Fig. 7, Table 2).

Radula (Fig. 1, 3B, 4B): the innermost lateral teeth are closely set at the anterior edge of ribbon segment, arranged in a posteriorly diverging $\mathrm{V}$-configuration and slightly curved backwards to the posterior tip of the tooth. C1 is blunt, with a straight ridge running from the middle of the base to the posterior tip of the tooth; medial edge convex, lateral edge straight. $\mathrm{C} 2$ is short, pointed: medial and lateral edges straight. The middle lateral tooth is posterior and lateral to the innermost tooth, closely situated longitudinally. It is slightly curved posteriorly-laterally and backwards. $\mathrm{C} 1$ is short, wide and pointed; medal edge convex; lateral edge concave. $\mathrm{C} 2$ is longer than $\mathrm{C} 1$ and $\mathrm{C} 3$, blunt, with a slight ridge running from the center of the base to the posterior tip of the tooth; medial and lateral edges are convex. C3 is short, wide and pointed; medial edge concave, lateral edge convex (Length Mlt/Wide Mlt Index = 1.23). The outermost lateral tooth is laterally situated towards the middle tooth. The cusp is triangular in lateral view, pointed: medial edge slightly convex to the base, lateral edge convex.

Radular sac (Fig. 1): the radular sac is medium in length. It extends backwards towards the middle of the visceral cavity and turns into two loops in the left anterior part of the visceral mass between the gonad and the digestive tract (Length Shell/Length Radula Index $=1.80$ ).

External anatomy (Fig. 1): the foot and the mantle fold are yellowish white coloured. The mantle fold is thin and bordered by a black narrow line. The mantle tentacles are in series that are alternated three little short ones and a slightly longer one and have no pigmentation. The cephalic tentacles have no pigmentation.

Distribution: Chilean-Peruvian Province, from Valparaíso through to Maullín. Depth range: $0-15 \mathrm{~m}$.

(4) Nacella (Patinigera) deaurata (Gmelin, 1791) (Fig. 1, 3D, 4D, 5A; Table 1)

Synonymy: Patella aenea Martyn, 1784: Vol. 1, pl. 1 (invalid). - Patella deaurata Gmelin, 1791: 3719; Strebel, 1907: 137, pl. 5, Figs. 62, 65, 68, 70; pl. 6, Figs. 76, 81; Carcelles, 1950: 52, pl. 1, Fig. 13. - Patella varicosa Reeve, 1854: pl. 11, Figs. 21A-C. - Nacella strigatella Rochebrune \& Mabille, 1885: Vol. 9, 110. - Nacella (Patinella) aenea Pilsbry, 1891: Vol. 13, 118, pl. 46, Figs. 28, 36. - Helcioniscus benneti Preston, 1913: 221, pl. 4, Fig. 7. - Nacella (Patinigera) aenea Wenz, 1938: 218, Fig. 401. - Patinigera aenea Powell, 1951: Vol. 26: 82. - Patinigera deaurata Dell, 1964: 273. - Nacella (Patinigera) deaurata subspecies deaurata Powell, 1973: 195, pl. 73, Fig. 11; pl. 174 Fig. 2; pl. 175, Figs. 3, 4; Ramírez, 1985: 56.

Material studied: Archipiélago Apiao $\left(42^{\circ} 35^{\prime} \mathrm{S} ; 73^{\circ} 13^{\prime} \mathrm{W}\right): \mathrm{n}=1$ UCCC: 5723. Bahía Laredo - Magallanes (5309' S; $70^{\circ} 55^{\prime}$ $\mathrm{W}): \mathrm{n}=5$ UCCC: 2392 . Bahía Orange (55³1' S; 68 03' W): n = 5 UCCC: 2391. Bahía Santa María - Tierra del Fuego $\left(53^{\circ} 21^{\prime} \mathrm{S} ; 70^{\circ} 58^{\prime} \mathrm{W}\right)$ : $\mathrm{n}=1$. Caleta Camden - Magallanes (53 $12^{\prime} \mathrm{S}$; $71^{\circ} 37^{\prime} \mathrm{W}$ ): 1 . Fuerte Bulnes (53 $37^{\circ} \mathrm{S} ; 7^{\circ} 56^{\prime}$ $\mathrm{W}): \mathrm{n}=2$. Hoste Island - Tanswani $\left(55^{\circ} 15^{\prime} \mathrm{S}\right.$; $\left.69^{\circ} 00^{\prime} \mathrm{W}\right): \mathrm{n}=6$ UCCC: 2345 . Hoste Island Canasaca $\left(55^{\circ} 15^{\prime} \mathrm{S} ; 69^{\circ} 01^{\prime} \mathrm{W}\right): \mathrm{n}=5$ 
UCCC:2680. Isla Diego Ramírez (56³0' S; $\left.68^{\circ} 44^{\prime} \mathrm{W}\right): \mathrm{n}=3$ UCCC: 2673 . Isla Summer $\left(52^{\circ} 20^{\prime} \mathrm{S} ; 7^{\circ} 40^{\prime} \mathrm{W}\right): \mathrm{n}=2$ UCCC: 5782. Playa Leña Dura - Magallanes (53 ${ }^{\circ} 13^{\prime} \mathrm{S}$; $\left.70^{\circ} 56^{\prime} \mathrm{W}\right): \mathrm{n}=8$ UCCC: 1325 . Puerto Clarencia $\left(52^{\circ} 54^{\prime} \mathrm{S} ; 70^{\circ} 06^{\prime} \mathrm{W}\right): \mathrm{n}=3$

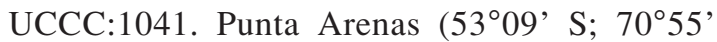
W): $\mathrm{n}=1$ UCCC: $1043 ; \mathrm{n}=3$ UCCC: $1055 ; \mathrm{n}=$ 1 UCCC: $10238 ; \mathrm{n}=1$ UCCC: $1042 ; \mathrm{n}=10$ UCCC: $1358 ; \mathrm{n}=16$ UCCC: 8063. Punta Chilota $\left(53^{\circ} 18^{\prime} \mathrm{S} ; 70^{\circ} 26^{\prime} \mathrm{W}\right): \mathrm{n}=10$ UCCC $: 1442 ; \mathrm{n}=2$ UCCC $: 10490 ; \mathrm{n}=8$ UCCC $: 1347 ; \mathrm{n}=2$ UCCC $: 6538 ; \mathrm{n}=10$ UCCC:10490. Punta Gusanos in Puerto Williams (54 $\left.56^{\prime} \mathrm{S} ; 6^{\circ} 37^{\prime} \mathrm{W}\right): \mathrm{n}=5$ UCCC: 4882; n $=5$ UCCC: 2542. Punta Santa María (5321' S; 7058' W): $\mathrm{n}=4$ UCCC: 15402 .

Description: shell (Fig. 1, 5A; Table 1): conical form, oblique, thick, relatively translucent. Big size (maximum length $55 \mathrm{~mm}$.), profile of medium height (Length/Height Index = 3.24; Length/Weight Index = 18.15). Apex situated at anterior $45 \%$ of the shell's length, obtuse. The anterior slope is slightly convex, the posterior is convex, and the lateral is nearly straight. Oval oblong aperture. Sculpture of numerous broad rounded radial ribs. Presence of well-defined concentric growth lines from the central zone towards the margin. Wave crenulated shell margin, corresponding to ribs projection. Primary ribs dark brown colored, that bifurcate towards the margin. Interspaces white. Soft nacreous interior, with a dun brown spot that corresponds to the animal body impression. Interior with radial dark brown lines and white interspaces corresponding to the exterior color pattern.

The non-metric multidimensional scaling (NMDS) ordination based on the measures of the shells, shows that $N$.(P.) deaurata presents a high degree of similarity with $N$. (P.) delicatissima (Fig. 7), but being clearly different of the other species of Nacella. The multivariate analysis of variance (MANOVA), shows that $N$. (P.) deaurata and $N$. (P.) delicatissima not presents statistically significant differences among them (Table 2). However, the clear differences in shell pigmentation and other characters (see below), permit the clear recognition of the species.

Radula (Fig. 1, 3D, 4D): the innermost lateral teeth are closely set at the anterior edge of ribbon segment, arranged in a posteriorly diverging $\mathrm{V}$-configuration and curved backwards towards the posterior tip of the tooth. $\mathrm{C} 1$ is the largest of all three teeth, sharply pointed, with a straight ridge running from the middle of the base to the posterior tip of the tooth; medial edge straight, lateral edge slightly convex. $\mathrm{C} 2$ is short, sharply pointed; medial and lateral edges straight. The middle lateral tooth is posterior and very lateral to the innermost tooth. It is curved postero-laterally and slightly curved backwards towards the margin. $\mathrm{C} 1$ is sharply pointed, with a curved ridge from the outer anterior corner of the base to the posterior tip of the tooth; medial and lateral edges convex. $\mathrm{C} 2$ is wider than $\mathrm{C} 1$, pointed; medial edge concave, lateral edge convex (Length Mlt/Wide Mlt Index = 1.72). The outermost lateral tooth is laterally situated to the middle tooth. The cusp is triangular in lateral view, blunt: medial and lateral edges convex.

Radular sac (Fig. 1): the radular sac is medium in length. It extends backwards to the middle of the visceral cavity and turns into two loops in the left anterior part of the visceral mass, between the gonad and the digestive tract. The second loop is projected to the posterior left margin overlapping the first loop in the posterior zone (Length Shell/Length Radula Index $=2.20$ ).

External anatomy (Fig. 1): The ventral area of the foot is greenish gray to the epipodial fringe. The mantle fold is thick and cream colored. The mantle tentacles are in series which are alternated by three white shorter ones and a black longer one. The cephalic tentacles are dorsally pigmented with black.

Distribution: Magellanic Province from Chiloé through Cape Horn, southern Patagonia and Falkland Islands (Powell 1973). Depth range: $0-30 \mathrm{~m}$.

(5) Nacella (Patinigera) delicatissima (Strebel, 1907) (Fig. 1, 3E, 4E, 5B; Table 1)

Synonymy: Patinella delicatissima Strebel, 1907: Vol. 25: 145, pl. 5, Figs. 71, 72, 74, 75; 1908: Vol. 6, pl. 1, Figs. 75, 75A. - Patella delicatissima Melvill \& Standen, 1914: 114; Carcelles, 1950: 52, pl. 1, Fig. 14. - Patinigera delicatissima Powell, 1951: Vol. 26, 82; Dell, 1964: 273. - Nacella (Patinigera) deaurata form delicatissima Powell, 1973: 195, pl. 178, Figs. 3, 4; Ramírez, 1985: 57. 

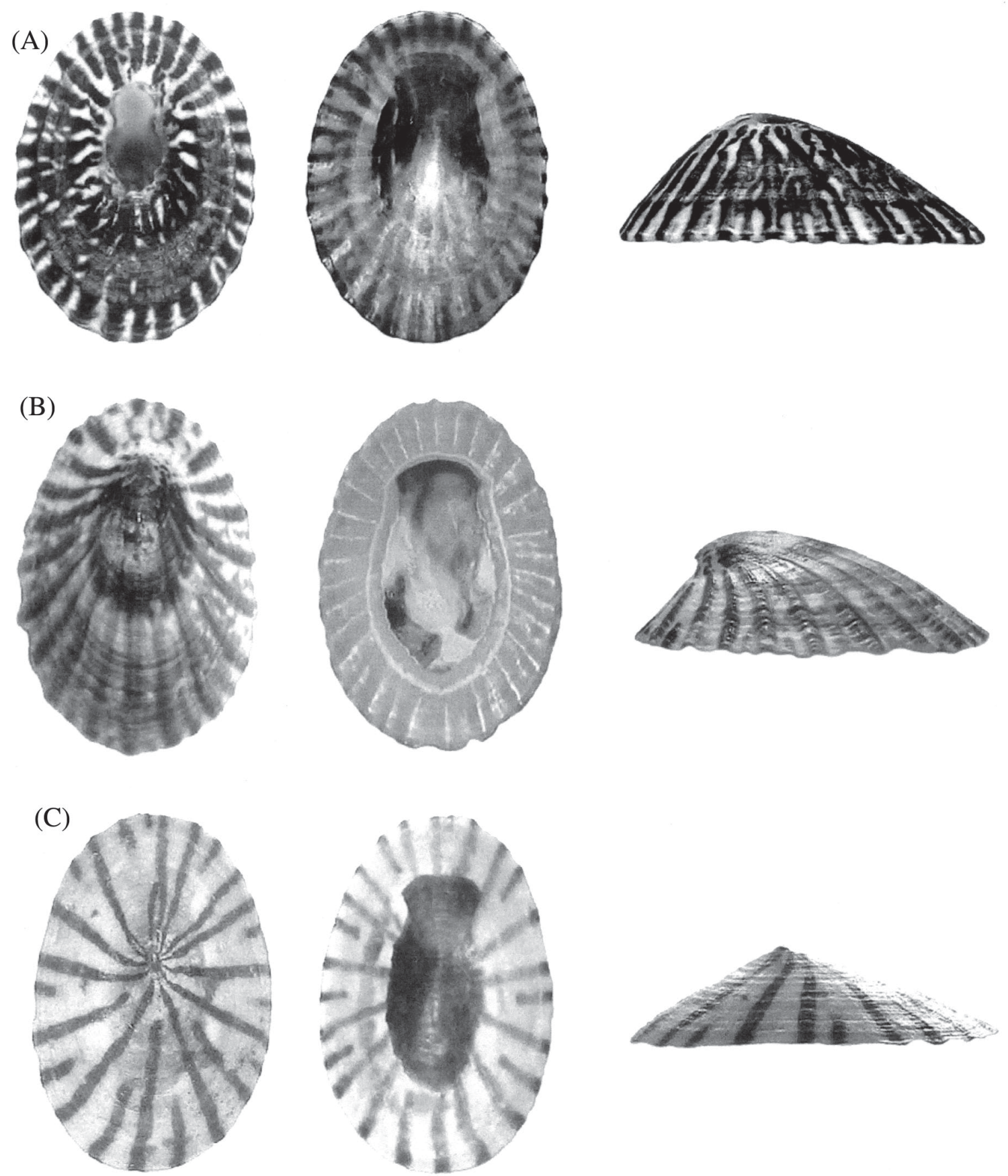

Fig. 5: Shells (dorsal, ventral and lateral views). (A) N. (P.) deaurata (length $55 \mathrm{~mm}$; UCCC: 1043); (B) N. (P.) delicatissima (length $37 \mathrm{~mm}$; UCCC: 2345); (C) N. (P.) flammea (length $39 \mathrm{~mm}$; UCCC: 1884).

Conchas (vistas dorsal, ventral y lateral). (A) N. (P.) deaurata (largo $55 \mathrm{~mm}$; UCCC: 1043); (B) N. (P.) delicatissima (largo $37 \mathrm{~mm}$; UCCC: 2345); (C) N. (P.) flammea (largo $39 \mathrm{~mm}$; UCCC: 1884). 
Material studied: Bahía Orange $\left(55^{\circ} 31^{\prime} \mathrm{S}\right.$; $\left.68^{\circ} 03^{\prime} \mathrm{W}\right): \mathrm{n}=1$ UCCC: 2391 . Hoste Island Tanswani $\left(55^{\circ} 15^{\prime} \mathrm{S} ; 6^{\circ} 00^{\prime} \mathrm{W}\right): \mathrm{n}=1 \mathrm{UCCC}$ : 2345. Hoste Island - Cansaca $\left(55^{\circ} 15^{\prime} \mathrm{S}\right.$; 69 $\left.{ }^{\circ} 00^{\prime} \mathrm{W}\right): \mathrm{n}=1$ UCCC: 2680. Isla Diego Ramírez (56 $30^{\circ}$ S; 68 $44^{\circ}$ ' W): $\mathrm{n}=1$ UCCC: 2673. Pargua $\left(41^{\circ} 47^{\prime} \mathrm{S} ; 73^{\circ} 25^{\prime} \mathrm{W}\right): \mathrm{n}=1$ UCCC: 6578. Puerto Williams ( $54^{\circ} 56^{\prime} \mathrm{S}$; $\left.67^{\circ} 37^{\prime} \mathrm{W}\right): \mathrm{n}=1$ UCCC: 6579. Punta Arenas $\left(53^{\circ} 09^{\prime} \mathrm{S} ; 70^{\circ} 55^{\prime} \mathrm{W}\right): \mathrm{n}=1$ UCCC: $10238 ; \mathrm{n}=$

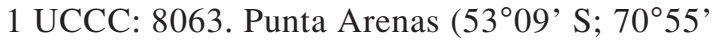
W) $: \mathrm{n}=2$ UCCC: 1059 . Punta Chilota $\left(53^{\circ} 18^{\prime}\right.$ S; 70²6' W): $\mathrm{n}=1$ UCCC: 10490 . Punta Santa María (53 $\left.21^{\prime} \mathrm{S} ; 70^{\circ} 58^{\prime} \mathrm{W}\right): \mathrm{n}=1$ UCCC: 6571. Río de los Ciervos (53 ${ }^{\circ} 12^{\prime}$ S; $\left.70^{\circ} 56^{\prime} \mathrm{W}\right)$ : $\mathrm{n}=3$ UCCC: $10274 ; \mathrm{n}=1$ UCCC: 2546.

Description: shell (Fig. 1, 5B; Table 1): conical form oblique, medium thickness, translucent. Small size (maximum length 37 $\mathrm{mm}$ ), profile of medium height (Length/Height Index $=3.38$; Length/Weight Index $=28.25$ ). Sharp pointed apex, anteriorly directed, situated at anterior $25 \%$ of the shell's length. The anterior slope is straight, the posterior is convex, and the lateral is slightly convex. Aperture oval oblong. Sculpture of raised rounded distant radial ribs. Presence of concentric growth lines form the central zone towards the margin. Wave crenulated shell margin, corresponding to ribs' projection. Exterior coloration pattern independent of ribbing: apical zone regular clear-brown stained and a few number of ribs are clear-brown colored; interspaces cream. Interior white nacreous, with a dun-brown spot that corresponds to the animal body impression; exterior markings visible through the shell.

The non-metric multidimensional scaling (NMDS) ordination based on the measures of the shells, shows that N.(P.) delicatissima presents a degree of similarity with $N$. (P.) deaurata and N. (N.) mytilina (Fig. 7), but being clearly different of the other species of Nacella. The multivariate analysis of variance (MANOVA), shows that $N$. (P.) chiloensis and $N$. (P.) mytilina presents statistically significant differences among them (Table 2), but not with $N$. (P.) deaurata. However, the clear differences in shell pigmentation and other characters (see below), permit the clear recognition of the species.

Radula (Fig. 1, 3E, 4E): the innermost lateral teeth are closely set at the anterior edge of ribbon segment, arranged in a posteriorly diverging V-configuration and slightly curved backwards towards the posterior tip of the tooth. C1 is the largest of all three teeth, pointed, with a straight ridge running from the middle of the base to the posterior tip of the tooth; medial edge straight, lateral edge slightly convex. C2 is short and thin, sharply pointed; medial edge straight, lateral edge slightly convex. The middle lateral tooth is posterior and lateral to the innermost tooth. It's curved postero-laterally and backward towards the margin. C1 is sharply pointed, with a curved ridge from the outer anterior corner of the base to the posterior tip of the tooth; medial edge convex, lateral edge slightly concave. $\mathrm{C} 2$ is wider than $\mathrm{C} 1$, blunt; medial edge slightly sigmoid, lateral edge convex (Length Mlt/Wide Mlt Index = 1.39). The outermost lateral tooth is laterally situated to the middle tooth. The cusp is triangular in lateral view, blunt: medial and lateral edges convex.

Radular sac (Fig. 1): the radular sac is long. It extends backwards to the middle of the visceral cavity and slightly curves towards the left margin in a straight form, and then turns into two loops in the left anterior part of the visceral mass, between the gonad and the digestive tract (Length Shell/Length Radula Index $=2.20$ ).

External anatomy (Fig. 1): the ventral area of the foot is dark greenish gray to the epipodial fringe. The mantle fold is thick and cream colored. The mantle tentacles are in series which are alternated of a long black one, a white shorter one and a grey short one. The cephalic tentacles are dorsally pigmented with black.

Distribution: Magellanic Province from Chiloé through Cape Horn. Falkland Islands (Powell 1973). Depth range: 0-16 m.

(6) Nacella (Patinigera) flammea (Gmelin, 1791) (Fig. 1, 5C; Table 1)

Synonymy: Patella flammea Gmelin, 1791: 3716, pl. 5, Fig. 42. - Patinella flammea Strebel, 1907: 145, pl. 5, Fig. 73. - Nacella (Patinigera) flammea Powell, 1973: 197, pl. 181; Ramírez, 1985: 57.

Material studied: Isla Guarello $\left(50^{\circ} 23^{\prime} \mathrm{S}\right.$; $\left.75^{\circ} 20^{\prime} \mathrm{W}\right): \mathrm{n}=1$ UCCC: 1884. Seno Almirantazgo $\left(54^{\circ} 25^{\prime} \mathrm{S} ; 6^{\circ} 50^{\prime} \mathrm{W}\right): \mathrm{n}=1$ 
UCCC: 1358 . Aysén $\left(46^{\circ} 26^{\prime} \mathrm{S} ; 7^{\circ} 45^{\prime} \mathrm{W}\right): \mathrm{n}=$ 1 UCCC 2635.

Description: shell (Fig. 1, 5C; Table 1): conical form, thin, relatively translucent, depressed. Medium size (maximum length 39 $\mathrm{mm}$ ), very low height profile (Length/Height Index $=4.56$; Length/Weight Index $=44.91$ ). Sharp pointed apex, situated at anterior $40 \%$ of the shell's length. All slopes straight. Aperture oval oblong. Sculpture of faint almost radial ribs. Presence of microscopic but well defined concentric growth lines, in all the surface. Shell margin relatively even. Coloration pattern independent of ribbing, with light brown fine rays. Some rays beginning below the apical zone, others at the margin. Interior with a nacreous halo and a dun-brown spot corresponding to the animal body impression. Coloration corresponding to external coloration pattern.

The non-metric multidimensional scaling (NMDS) ordination and the multivariate analysis of variance (MANOVA), based on the measures of the shells, shows that N.(N.) flammea is clearly different of the other species of Nacella. (Fig. 7, Table 2).

Distribution: Magellanic Province from Aysén through Magellan Strait. Depth range: 5$20 \mathrm{~m}$.

(7) Nacella (Patinigera) magellanica (Gmelin, 1791) (Fig. 1, 3F, 4F, 6A; Table 1)

Synonymy: Patella magellanica Gmelin, 1791: 3703; Reeve, 1854: pl.10, Figs. 19A,B; Carcelles, 1950: 52, pl. 1, Fig. 12. - Patella atramentosa Reeve, 1854: pl. 17, Figs. 41A,B. - Patella fuegiensis Reeve, 1855: Conch. Iconica, pl. 28, Figs. 73A,B. - Patella meridionalis Rochebrune \& Mabille, 1885: Vol. 9: 109. - Patella metallica Rochebrune \& Mabille, 1885: Vol. 9: 109. - Patella pupillata Rochebrune \& Mabille, 1885: Vol. 9: 110. Patella tincta Rochebrune \& Mabille, 1885: Vol. 9: 110. - Patinella aenea var. magellanica Pilsbry, 1891: 119, pl. 44, Figs. 9, 12, 15, 16, pl. 43, Figs 1, 6. - Nacella (Patinella) fuegiensis Reeve, Pilsbry, 1891. Man. Conch., vol. 13, p. 121, pl. 49. Figs. 30, 31. - Patinella magellanica atramentosa Strebel, 1907: Vol. 25: 146, pl. 6, Figs. 86, 88; pl. 7, Figs. 91, 92, 94, 95. - Patinella aenea var. minor Strebel, 1907: Vol. 25: 137, pl. 5, Figs. 67 a-d. -
Patinigera magellanica Powell, 1951: Vol. 26, 81; Dell, 1964: 273; 1971, 204. - Nacella (Patinigera) magellanica subspecies magellanica Powell, 1973: 198, pl. 73, Figs 14, 15; pl. 178, Figs. 1, 2; Ramírez, 1985: 54. Nacella fuegiensis Powell, 1973. Indo-Pacific Mollusca, vol. 3 (15), p. 197-198, pl. 177, Figs. $1,2$.

Material studied: Ancud Playa Castillo (4152' S; 7350' W): $\mathrm{n}=1$ UCCC: 2391. Bahía Orange $\left(55^{\circ} 31^{\prime} \mathrm{S} ; 68^{\circ} 03^{\prime} \mathrm{W}\right): \mathrm{n}=4$ UCCC: 2391; $\mathrm{n}=4$ UCCC: 2344 ; $\mathrm{n}=9$ UCCC: 2344. Bahía Santa María - Tierra del Fuego $\left(53^{\circ} 21^{\prime} \mathrm{S} ; 70^{\circ} 58^{\prime} \mathrm{W}\right): \mathrm{n}=2$ UCCC: 2361. Calbuco-Puerto Montt ( $41^{\circ} 46^{\prime} \mathrm{S}$; $\left.73^{\circ} 07^{\prime} \mathrm{W}\right)$ : n $=4$ UCCC: 1450 . Caleta Camden $\left(53^{\circ} 12^{\prime} \mathrm{S}\right.$; $\left.71^{\circ} 37^{\prime} \mathrm{W}\right): \mathrm{n}=11 \mathrm{UCCC}: 1326 ; \mathrm{n}=3$ UCCC: 1329; $\mathrm{n}=5$ UCCC: 1343. Hoste IslandCanasaca $\left(55^{\circ} 15^{\prime} \mathrm{S} ; 69^{\circ} 00^{\prime} \mathrm{W}\right): \mathrm{n}=1 \mathrm{UCCC}$ : 2539. Estero Chope $\left(53^{\circ} 24^{\prime} \mathrm{S} ; 72^{\circ} 52^{\prime} \mathrm{W}\right): \mathrm{n}=$ 8. Fiordo Parry $\left(53^{\circ} 31^{\prime} \mathrm{S} ; 6^{\circ} 15^{\prime} \mathrm{W}\right): \mathrm{n}=2$ UCCC: 2398. Islas Diego Ramírez (56³0’ S; 68 $\left.44^{\prime} \mathrm{W}\right): \mathrm{n}=1$ UCCC: 2673. Isla Guarello $\left(50^{\circ} 23^{\prime} \mathrm{S} ; 75^{\circ} 20^{\prime} \mathrm{W}\right): \mathrm{n}=1$ UCCC: $1433 ; \mathrm{n}=$ 12 UCCC: 10391; $\mathrm{n}=2$ UCCC: $2293 ; \mathrm{n}=29$ UCCC: $15379 ; \mathrm{n}=41$ UCCC: $10390 ; \mathrm{n}=9$ UCCC: 1328 . Isla López $\left(50^{\circ} 22^{\prime} \mathrm{S} ; 7^{\circ} 19^{\prime} \mathrm{W}\right)$ : $\mathrm{n}=4$ UCCC: 15492 . Isla San Félix $\left(26^{\circ} 17^{\prime} \mathrm{S}\right.$; $\left.80^{\circ} 05^{\prime} \mathrm{W}\right): \mathrm{n}=10$ UCCC: 10240 . Isla Summer $\left(52^{\circ} 20^{\prime} \mathrm{S} ; 7^{\circ} 40^{\prime} \mathrm{W}\right): \mathrm{n}=8$ UCCC: 6501. Pargua $\left(41^{\circ} 47^{\prime} \mathrm{S} ; 73^{\circ} 25^{\prime} \mathrm{W}\right): \mathrm{n}=29$ UCCC: 6578; $\mathrm{n}=36$ UCCC: $5754 ; \mathrm{n}=37$ UCCC: 6502; Puerto Williams Magallanes (54 ${ }^{\circ} 56^{\prime} \mathrm{S}$; $\left.67^{\circ} 37^{\prime} \mathrm{W}\right): \mathrm{n}=1$ UCCC: 2541. PumalínChiloé Island $\left(42^{\circ} 41^{\prime} \mathrm{S} ; 72^{\circ} 49^{\prime} \mathrm{W}\right): \mathrm{n}=25$

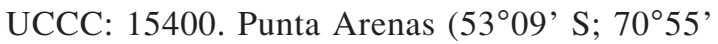
$\mathrm{W}): \mathrm{n}=2$ UCCC: $1055 ; \mathrm{n}=5$ UCCC: 1059. Punta Chilota-Magallanes (53 ${ }^{\circ} 18^{\prime}$ S; $70^{\circ} 26^{\prime}$ $\mathrm{W}): \mathrm{n}=1$ UCCC:10490; $\mathrm{n}=11$ UCCC: 117 ; $=4$ UCCC: $1324 ; \mathrm{n}=6$ UCCC: $118 ; \mathrm{n}=5$ UCCC: 118. Puerto Williams-Punta Gusanos (5456' S; $\left.67^{\circ} 37^{\prime} \mathrm{W}\right): \mathrm{n}=1$ UCCC: $15457 ; \mathrm{n}=$ 3 UCCC: 4882. Seno Agostini-V. Vergara $\left(54^{\circ} 26^{\prime} \mathrm{S} ; 70^{\circ} 26^{\prime} \mathrm{W}\right): \mathrm{n}=2$. Seno OtwayMagallanes $\left(53^{\circ} 00^{\prime} \mathrm{S} ; 71^{\circ} 30^{\prime} \mathrm{W}\right): \mathrm{n}=1$ UCCC: 2291.

Description: shell (Fig. 1, 6A; Table 1): conical form, very thick, not translucent, laterally compressed in the anterior zone. Large size (maximum length $62.5 \mathrm{~mm}$ ), profile high (Length/Height Index $=1.88$; Length/Weight Index $=5.31$ ). Apex situated at anterior $45 \%$ of the shell's length, obtuse. All slopes convex 
(particularly the posterior one). Aperture oval. Sculpture of raised angular primary radial ribs, with weaker secondary ribs. Presence of concentric growth lines, notorious in the interspaces. Deeply angular crenulated shell margin, corresponding to ribs' projection. Exterior coloration variable (pale reddish brown to greenish gray or dull- brown). Primary and secondary ribs brown ash-colored to dark brown, interspaces cream. Soft metallic brown interior, with dark lines corresponding to exterior color pattern, bordered by a pearlybrown halo.

The non-metric multidimensional scaling (NMDS) ordination based on the measures of the shells, shows that $N$.(P.) magellanica presents a degree of similarity with $N$. (P.) chiloensis and $N$. (P.) venosa (Fig. 7), but being clearly different of the other species of Nacella. The multivariate analysis of variance (MANOVA), shows that $N$. (P.) magellanica, and $N$. (P.) delicatissima and $N$. (P.) chiloensis presents statistically significant differences among them (Table 2).

Radula (Fig. 1, 3F, 4F): the innermost lateral teeth are closely set at the anterior edge of ribbon segment, arranged in a posteriorly diverging $\mathrm{V}$-configuration, and slightly curved backwards towards the posterior tip of the tooth. C1 is long and sharply pointed, with a straight ridge running from the middle of the base towards the posterior tip of the tooth; medial edge slightly convex, lateral edge sigmoid. C2 is short and thin, pointed; medial edge slightly concave, lateral edge convex. The middle lateral tooth is posterior and very lateral to the innermost. It is curved postero-laterally and backwards. $\mathrm{C} 1$ is long and sharply pointed, with a curved ridge from the outer anterior corner of the base to the posterior tip of the tooth; medial edge convex, lateral edge slightly concave. $\mathrm{C} 2$ is wide, broad and pointed; medial edge concave, lateral edge convex (Length Mlt/ Wide Mlt Index $=1.38$ ). The outermost lateral tooth is laterally situated to the middle tooth. The cusp is triangular in lateral view, medial and lateral edges convex.

Radular sac (Fig. 1): the radular sac is very long. It extends backwards to the middle of the visceral cavity coiling in four ventrally directed loops in the left anterior part of the visceral mass, between the gonad and the digestive tract (Length Shell/Length Radula Index $=3.40$ ).
External anatomy (Fig. 1): the ventral area of the foot is greenish gray. The mantle fold is thick and dun brown colored. The mantle tentacles are in series which alternate a white shorter one and a white slightly longer one. The cephalic tentacles are dorsally pigmented with black.

Distribution: Magellanic Province from Chiloé through Cape Horn, southern Patagonia and Falkland Islands (Powell 1973). Depth range: 0-25 $\mathrm{m}$.

(8) Nacella (Patinigera) venosa (Reeve, 1854) (Fig. 1, 3G, 4G, 6B; Table 1)

Synonymy: Patella venosa Reeve, 1854: pl. 10, Figs. 18A-C. - Patinella venosa Strebel, 1907: 150, pl. 7, Fig. 93.- Patinigera magellanica venosa Dell, 1964: 273. - Nacella (Patinigera) subspecies venosa Powell, 1973: 198, pl. 180, Figs. 1, 2 (Note: The Figures of the Pl. 180 from Powell, have an error in their numeration, in relation with those of Reeve. The correct numbers for venosa form are 3, 4); Ramírez, 1985: 54.

Material studied: Ancud-Playa Castillo (41 ${ }^{\circ} 52^{\prime} \mathrm{S} ; 73^{\circ} 50$ ' W): $\mathrm{n}=4$ UCCC: 2271. Archipiélago Apiao-Chiloé $\left(42^{\circ} 35^{\prime} \mathrm{S}\right.$; $73^{\circ} 13^{\prime}$ $\mathrm{W}): \mathrm{n}=1$ UCCC: 5723 . Canasaca-Hoste Island $\left(55^{\circ} 15^{\prime} \mathrm{S} ; 69^{\circ} 00^{\prime} \mathrm{W}\right): \mathrm{n}=1 \mathrm{UCCC}: 2545$. Cerro Colorado $\left(49^{\circ} 32^{\prime} \mathrm{S} ; 7^{\circ} 14^{\prime} \mathrm{W}\right): \mathrm{n}=1$ UCCC: 2272. Pargua $\left(41^{\circ} 47^{\prime} \mathrm{S} ; 73^{\circ} 25^{\prime} \mathrm{W}\right): \mathrm{n}=13$ UCCC: $6502 ; \mathrm{n}=21$ UCCC: $5754 ; \mathrm{n}=24$ UCCC: 6578. Piedra Azul-Puerto Montt (41ํำ S; $\left.72^{\circ} 55^{\prime} \mathrm{W}\right): \mathrm{n}=1$ UCCC: 1057. Pumalín

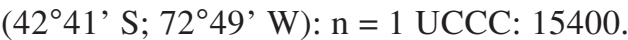

Description: shell (Fig. 1, 6B; Table 1): conical form, medium thickness, relatively translucent, laterally compressed in the anterior zone. Small size (maximum length $35 \mathrm{~mm}$ ), medium height profile (Length/Height Index = 2.29; Length/Weight Index = 13.39). Sharp pointed apex, situated at anterior $40 \%$ of the shell length. All slopes convex. Aperture oval. Sculpture of weak and distant ribs, absent in adult specimens. Presence of concentric growth lines, notorious in all the surface. Smooth shell margin. Exterior color pattern independent of ribbing: apical zone irregular brown spotted, with varicose radial lines that bifurcate towards the margin; interspaces white. Interior with a dull brown spot that corresponds to the animal body impression, radiate for varicose lines that correspond to the exterior color pattern, intermediate area with a metallic-brown halo. 
TABLE 2

Multivariate analysis of variance (MANOVA) among the Chilean species of Nacella, using the shell measurements (Length / Width Index, Length / Height Index, Length / Apex-anterior Index and Length / Weight Index)

Análisis multivariado de varianza (MANOVA) entre las especies chilenas de Nacella, empleando las medidas de la concha (índice Largo / Ancho, índice Largo / Alto, índice Largo / Ápice-anterior e índice Largo / Peso)

\begin{tabular}{|c|c|c|c|c|c|}
\hline Species & $\begin{array}{l}\text { Wilks' } \\
\text { Lambda }\end{array}$ & $\begin{array}{c}\text { F- } \\
\text { value }\end{array}$ & $\begin{array}{c}\text { Effect } \\
\text { degrees of } \\
\text { freedom }\end{array}$ & $\begin{array}{c}\text { Error } \\
\text { degrees of } \\
\text { freedom }\end{array}$ & $\begin{array}{c}\text { P- } \\
\text { value }\end{array}$ \\
\hline$N$. (P.) deaurata $x N$. (P.) venosa & 0.037 & 97.0 & 4 & 15 & $<0.0001$ \\
\hline$N$. (P.) deaurata $x N$. (P.) chiloensis & 0.034 & 106.5 & 4 & 15 & $<0.0001$ \\
\hline$N$. (P.) deaurata $x N$. (P.) magellanica & 0.080 & 43.2 & 4 & 15 & $<0.0001$ \\
\hline$N .(P$.$) deaurata x N$. (N.) mytilina & 0.187 & 16.3 & 4 & 15 & $<0.0001$ \\
\hline$N .(P$.$) deaurata x N$. (P.) clypeater & 0.032 & 113.3 & 4 & 15 & $<0.0001$ \\
\hline$N .(P$.$) deaurata x N$. (P.) delicatissima & 0.869 & 0.6 & 4 & 15 & n.s. \\
\hline$N$. (P.) deaurata $x N$. (P.) flamea & 0.114 & 15.5 & 4 & 8 & $<0.005$ \\
\hline$N .(P$.$) venosa x N .(P$.$) chiloensis$ & 0.456 & 4.5 & 4 & 15 & n.s. \\
\hline$N$. (P.) venosa $\times N$. (P.) magellanica & 0.217 & 13.5 & 4 & 15 & $<0.0001$ \\
\hline$N$. (P.) venosa $x N$. (N.) mytilina & 0.025 & 144.5 & 4 & 15 & $<0.0001$ \\
\hline$N$. (P.) venosa $x N$. (P.) clypeater & 0.024 & 152.8 & 4 & 15 & $<0.0001$ \\
\hline$N$. (P.) venosa $x N$. (P.) delicatissima & 0.071 & 49.2 & 4 & 15 & $<0.0001$ \\
\hline$N$. (P.) venosa $x N$. (P.) flamea & 0.006 & 339.7 & 4 & 8 & $<0.0001$ \\
\hline$N .(P$.$) chiloensis x N$. (P.) magellanica & 0.216 & 13.6 & 4 & 15 & $<0.0001$ \\
\hline$N .(P$.$) chiloensis x N$. (N.) mytilina & 0.023 & 157.5 & 4 & 15 & $<0.0001$ \\
\hline$N .(P$.$) chiloensis x N$. (P.) clypeater & 0.022 & 164.2 & 4 & 15 & $<0.0001$ \\
\hline$N .(P$.$) chiloesis x N$. (P.) delicatissima & 0.063 & 55.5 & 4 & 15 & $<0.0001$ \\
\hline$N$. (P.) chiloensis $x N$. (P.) flamea & 0.011 & 185.0 & 4 & 8 & $<0.0001$ \\
\hline$N .(P$.$) magellanica x N$. (N.) mytilina & 0.032 & 112.7 & 4 & 15 & $<0.0001$ \\
\hline$N .(P$.$) magellanica x N$. (P.) clypeater & 0.024 & 150.2 & 4 & 15 & $<0.0001$ \\
\hline$N$. (P.) magellanica $x N$. (P.) delicatissima & 0.112 & 29.7 & 4 & 15 & $<0.0001$ \\
\hline$N$. (P.) magellanica $x N$. (P.) flamea & 0.018 & 106.6 & 4 & 8 & $<0.0001$ \\
\hline$N .(N$.$) mytilina x N .(P$.$) clypeater$ & 0.029 & 127.0 & 4 & 15 & $<0.0001$ \\
\hline$N .(N$.$) mytilina x N$. (P.) delicatissima & 0.258 & 10.8 & 4 & 15 & $<0.005$ \\
\hline$N$. (N.) mytilina $x N$. (P.) flamea & 0.022 & 90.6 & 4 & 8 & $<0.0001$ \\
\hline$N$. (P.) clypeater $x N$. (P.) delicatissima & 0.027 & 136.1 & 4 & 15 & $<0.0001$ \\
\hline$N$. (P.) clypeater $x N$. (P.) flamea & 0.061 & 30.8 & 4 & 8 & $<0.0001$ \\
\hline$N$. (P.) delicatissima $x N$. (P.) flamea & 0.053 & 35.7 & 4 & 8 & $<0.0001$ \\
\hline
\end{tabular}



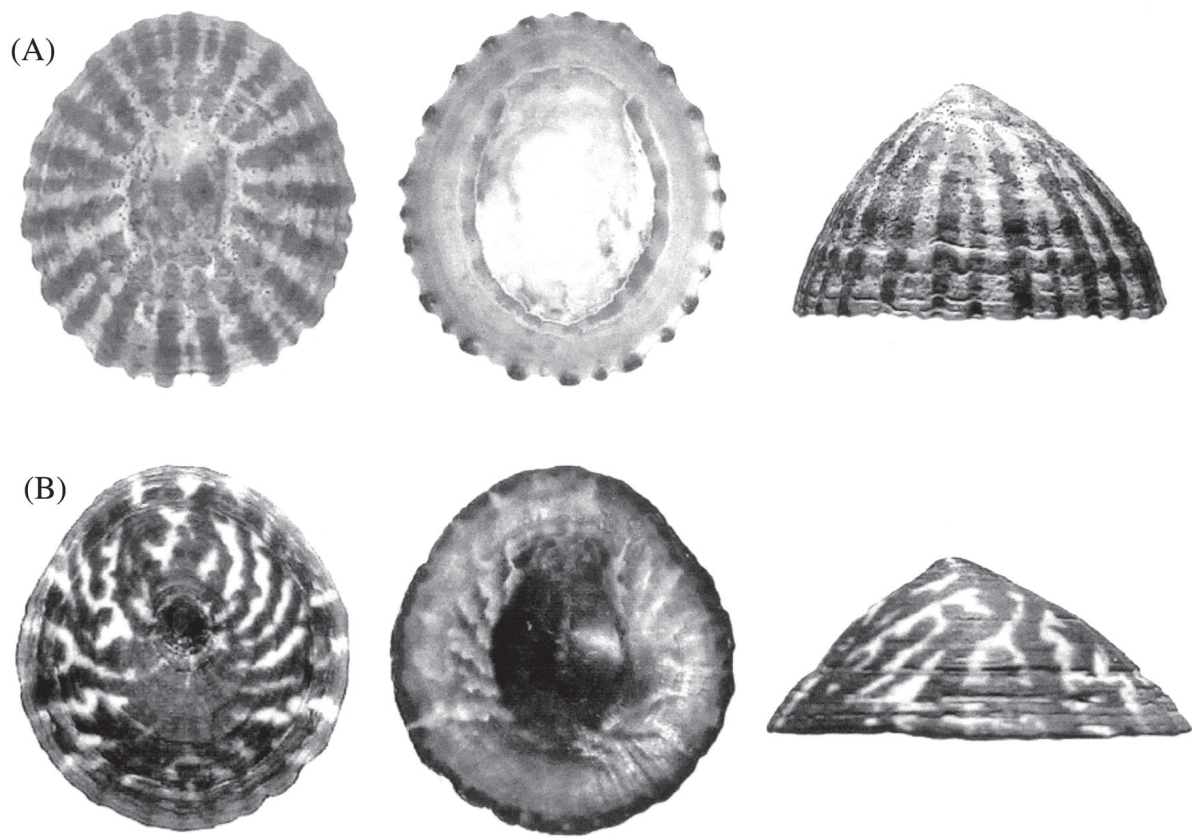

Fig 6: Shells (dorsal, ventral and lateral views). (A) N. (P.) magellanica (length $62.5 \mathrm{~mm}$; UCCC: 2391); (B) N. (P.) venosa (length $35 \mathrm{~mm}$; UCCC: 5723).

Conchas (vistas dorsal, ventral y lateral). (A) N. (P.) magellanica (largo $62.5 \mathrm{~mm}$; UCCC: 2391); (B) N. (P.) venosa (largo $35 \mathrm{~mm}$; UCCC: 5723).

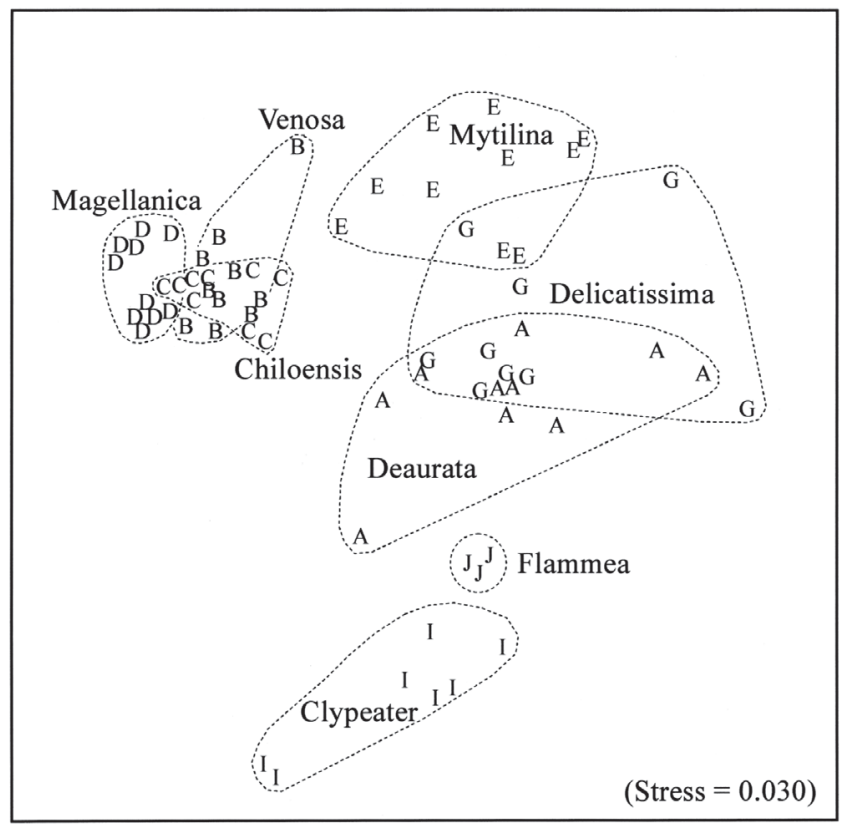

Fig 7: NMDS ordination of specimens different species of Chilean Nacellidae, using data of shell morphometry. $\mathrm{A}=N$. (P.) deaurata, $\mathrm{B}=N$. (P.) venosa, $C=N$. (P.) chiloensis, $\mathrm{D}=N .(P$. magellanica, $\mathrm{E}=N$. (N.) mytilina, $\mathrm{F}=N$. (P.) clypeater, $\mathrm{G}=N$. $(P$.) delicatissima, $\mathrm{J}=N$. $(P$.) flammea.

Ordenación NMDS de ejemplares de diferentes especies de Nacellidae chilenos, empleando datos de la morfología de la concha. $\mathrm{A}=N$. $(P$.) deaurata, $\mathrm{B}=N$. (P.) venosa, $\mathrm{C}=N$. $(P$.) chiloensis, $\mathrm{D}=N$. $(P$.) magellanica, $\mathrm{E}=N$. $(N$.) mytilina, $\mathrm{I}=$ $N$. (P.) clypeater, $\mathrm{G}=N$. (P.) delicatissima, $\mathrm{J}=N$. (P.) flammea . 
The non-metric multidimensional scaling (NMDS) ordination based on the measures of the shells, shows that $N$.(P.) venosa presents a degree of similarity with $N$. (P.) magellanica and $N$. (P.) chiloensis (Fig. 7), but being clearly different of the other species of Nacella. The multivariate analysis of variance (MANOVA), shows that $N$. (P.) venosa and $N$. (P.) magellanica presents statistically significant differences among them (Table 2), but not with $N$. (P.) chiloensis. However, the clear differences in shell pigmentation and other characters (see below), permit the clear recognition of the species.

Radula (Fig. 1, 3G, 4G): the innermost lateral teeth are closely set at the anterior edge of ribbon segment, arranged in a posteriorly diverging V-configuration and slightly curved backwards towards the posterior tip of the tooth. $\mathrm{C} 1$ is long, pointed, with a straight broad ridge running from the middle of the base towards the posterior tip of the tooth, medial edge straight, lateral edge concave. $\mathrm{C} 2$ is short, blunt: medial edge slightly convex, lateral edge sigmoid. The middle lateral tooth is posterior and lateral to the innermost tooth. It is curved postero-laterally and backward. $\mathrm{C} 1$ is the largest of all three teeth, blunt, with a curved ridge from the outer anterior corner of the base towards the posterior tip of the tooth; medial edge convex, lateral edge concave. $\mathrm{C} 2$ is short and wider than $\mathrm{C} 1$; medial and lateral edges slightly convex (Length Mlt/Wide Mlt Index = 1.64). The outermost lateral tooth is reduced in size and laterally situated to the middle tooth. The cusp is triangular in lateral view and has a wedge-like shape in dorsal view, pointed; medial and lateral edges convex.

Radular sac (Fig. 1): the radular sac is long. It extends backwards to the middle of the visceral cavity coiling in three ventrally directed loops in the left anterior part of the visceral mass, between the gonad and the digestive tract (Length Shell/Length Radula Index $=2.20$ ).

External anatomy (Fig. 1): the ventral area of the foot is dark greenish gray to the epipodial fringe. The mantle fold is thin and cream colored. The mantle tentacles are in series which are alternated of three white little short ones and a longer dark gray one. The cephalic tentacles are dorsally pigmented in black.
Distribution: Magellanic Province from Chiloé through Cape Horn. Depth range: 0-10 m.

\section{DISCUSSION}

\section{Taxonomy}

The examination of the Nacellidae of the Chilean coasts has resulted in the recognition of one species of $N$. (Nacella) and seven species of $N$. (Patinigera), wherein the principal specific differences are in the shell (shape, thickness and color) and in radular teeth morphology. A multivariate analysis of the shell morphometry of different specimens of Nacella using NMDS as technique of ordination (Fig. 7), show the high degree of similarity of the shell morphology of some groups of species, i.e., group magellanica - chiloensis - venosa, and group delicatissima deaurata. On the other hand, mytilina, shows clear different morphological patterns. A multivariate analysis of variance (MANOVA) between the Chilean species of Nacella (Table 2), using the shell measurements (Length / Width Index, Length / Height Index, Length / Apex-anterior Index and Length / Weight), shows that only the species $N$. (P.) deaurata and $N$. (P.) delicatissima, and the species $N$. (P.) venosa and $N$. (P.) chiloensis, not presents sharp differences in shell morphometry $(\mathrm{p}<$ 0.0001 ), and it is necessary to consider other additional taxonomic characters as color and sculpture of the shell, and radular morphology.

In Powell's (1973) review, on the basis of shell characteristics, $N$. (P.) chiloensis and $N$. $(P$.) venosa were considered as subspecies of $N$. $(P$.) magellanica. It is considered on the basis of a combination between morphometric analysis of the shell, and the study of the radular teeth, that they are three different species. On basis of the same characters, we consider Nacella fuegiensis Powell, 1973 as synonym of $N$. (P.) magellanica.

The shell of $N$. (P.) venosa is clearly different from the other two species. The sculpture of this species is composed of weak and distant ribs, which are absent in adult specimens. This species also presents a different external pigmentation with brown varicose radial lines that bifurcate towards the margin. Typical characteristics of the radula of 
this species are observed in the innermost lateral teeth. The medial edge of $\mathrm{C} 1$ is straight and the lateral edge concave, and $\mathrm{C} 2$ is short and wider than $\mathrm{C} 1$. On the other hand, the cusp of the outermost lateral tooth is triangular in lateral view and has a wedge-like shape in dorsal view, pointed. In general, the shells of $N$. (P) magellanica and $N$. (P.) chiloensis are very similar in shape and pigmentation. However, in the first species the apex is situated at anterior $45 \%$ of the shell's length, and obtuse. All slopes of this species are convex, particularly in the posterior end. The second species present a sharp pointed apex, situated at anterior $40 \%$ of the shell's length. All slopes of this species are slightly convex. In constrast to the shell, the tooth of the radula of the two species reveal clear differences. $N .(P)$ magellanica, in the innermost lateral teeth, $\mathrm{C} 1$ presents the medial edge slightly convex and the lateral edge sigmoid; $\mathrm{C} 2$ is thin and pointed with the medial edge slightly concave, and the lateral edge convex. The medial and lateral edges of the outermost lateral tooth are convex. In contrast, in $N$. (P.) chiloensis, in the innermost lateral teeth, $\mathrm{C} 1$ present the medial edge straight and the lateral edge concave; C2 is blunt with medial edge straight, lateral edge sigmoid. The medial and lateral edges of the outermost lateral tooth are straight.

Powell (1973) considers N. (P.) delicatissima a subspecies of $N$. (P.) deaurata. The data of this study suggest that it is incorrect. In general, the shape and coloration of the shell are very similar, however they present some clear differences. The shell of the first species presents a sharp pointed apex, anteriorly directed, and situated at anterior 25 $\%$ of the shell's length; the anterior slope is straight, the posterior is convex, and the lateral is slightly convex. In the second species, the apex is situated at anterior $45 \%$ of the shell's length and is obtuse, and the anterior slope is slightly convex, the posterior is convex, and the lateral is nearly straight. The radula also presents clear differences, i.e. the Length Mlt/ Wide Mlt Index (7.7 deaurata and 1.4 delicatissima).

Nacella (N.) mytilina is a species very easy to recognize through the structure and coloration of the shell. This is very thin, oblique (laterally compressed) and pearly cream. In general, the shape of the shell of $N$.
(N.) mytilina is similar to Nacella (P.) delicatissima, while the position of the apex, sculpture and coloration are clearly different. $N$. (P.) flammea is a species clearly different of the other Chilean species of Nacella and very easy to recognize, through the depressed form (very low height profile), and the typical coloration of the shell (light brown fine rays). We did not study the radula and soft parts of $N$. $(P$.$) flammea, but the clear differences of the$ shell with the other species of the genus suggest that it corresponds to a valid species. The shell and radula of $N$. (P.) clypeater are very distinct of the other species of Nacella, for the oval aperture and the very low height profile, and the short and wide C1 cusp on the of middle lateral tooth of the radula.

Many authors have discussed the problems of taxonomic limpet studies regarding the fluctuations in environmental conditions. In general the different species of limpets tend to vary in size, form, sculpture and coloration, due to the relative exposure to wave stress and the nature of the substratum (Powell 1951, 1973, Dell 1964, 1971, Branch 1975, Lindberg \& McLean 1981, Garrity 1984, Sasaki \& Okutani 1993a, 1993b, 1994a, 1994b). According to Vermeij (1973), this variation reveals the existence of intra- and interspecific morphological gradients, as an adaptative strategy to environmental rigor. This author also suggests that these morphological changes follow a bathymetrical pattern roughly equivalent to that observed going from low to high latitudes. The Chilean species of Nacella also show a clear interspecific pattern which allows to suggest a link between the life form (habitat and environmental rigurosity) and the shell morphology. The species living on rocky shores of intertidal environments very exposed to the waves and currents, have high and strong shells and big pedal muscles (e.g., $N$. (P.) magellanica, $N$. (P.) chiloensis and $N .(P$. venosa). In contrast, species that live in non exposed rocky shores of subtidal environments, have low and thin shells (e.g., $N$. (P.) clypeater, $N$. (P.) delicatissima and $N$. (P.) flammea). On the other hand, $N$. (N.) mytilina, living mostly attached to large seaweeds in subtidal environments, presents intermediate characteristics. This morphologic pattern is probably also linked to feeding habits, however unknown for most species. 


\section{Distribution}

The genus Nacella and its subgenus Patinigera are cold-water limpets, and are exclusively inhabitants of subantarctic and Antarctic waters. The greater part of their range being subantarctic, but extending to the Antarctic by way of the Scotia Arc, and also ranging northward up the Chilean coast to at least Valparaíso at $33^{\circ} \mathrm{S}$ (only $N$. (P.) clypeater), probably assisted by the upwelling of cold water along that coast. They apparently have their centre of distribution in the Magellanic Province of southern South America, wherefrom the larval transport is probably assisted by the considerable extent by the prevailing West Wind Drift which strongly operates in the Subantarctic Zone. Furthermore, many of the species live upon the large kelps which probably provide an effective means of chance dispersal when parts of the weed are wrenched free and drift before wind and current. The farthest eastward that this genus has established itself is Kerguelen Island, and the subgenus Patinigera in Campbell Island (Powell 1973).

According to Viviani (1979) and Fernández et al. (2000), four distinct areas can be identified along the Chilean coast: (i) arid coast; (ii) semiarid coast; (iii) central coast and (iv) fjords coast. In Chile, the genus Nacella is only found in the central coast (one species) and fjords coast (seven species). The central coast extends between approximately $32^{\circ} \mathrm{S}$ and $42^{\circ} \mathrm{S}$, and is only inhabited by $N .(P)$ clypeater, corresponding to the northern limit of distribution for the genus. The fjords coast extends from about $43^{\circ} 30^{\prime}$ through $56^{\circ} \mathrm{S}$, and according to Pickard (1971), is one of the best examples of deep and rugged fjord coasts in the world. This area presents the highest diversity of the genus Nacella, with the species N.(N.) mytilina, N.(P.) chiloensis, N.(P.) deaurata, N.(P.) delicatissima, N.(P.) flammea, N.(P.) magellanica and $N .(P$.) venosa. In this region the average seawater temperature is the lowest of the Chilean coast (from $12^{\circ} \mathrm{C}$ in the north to $6^{\circ} \mathrm{C}$ in the south), and the shoreline is highly indented because the fjords penetrate inland through the glacially dissected Andes mountains. In addition, the fjords coast presents the highest shelf area along the Chilean coast. The high diversity of the genus Nacella in the fjords coast is also observed in other groups of mollusks. According to Valdovinos et al. (2003), the trend in mollusk diversity may be the result of higher diversification of mollusks at higher latitudes, south of $42^{\circ} \mathrm{S}$. The use of discrete refugia may have enabled taxa to survive repeated glacial advances over the past 40 million years, and the consequent fragmentation and isolation of mollusk distributional areas, could have actually favored the diversification of species in the Magellan fjords (Crame 1997), conforming a pocket of high taxonomic diversity at these latitudes. In addition, at ca. $42^{\circ} \mathrm{S}$ there is a divergence of major oceanic currents (Castilla et al. 1993, Escribano et al. 2003), which apparently leads to the relative isolation of the marine fauna within the Magellan fjords.

\section{ACKNOWLEDGEMENTS}

We gratefully thank Dr. José Stuardo for his assistance with valuable practical suggestions on taxonomic problems, literature and materials. We also thank Dr. Sergio Navarrete, Pablo Marquet and Dirección de Investigación de la Universidad de Concepción for the facilities given for this study. Our special thanks are due to the following persons who kindly provided us plentiful shell and preserved materials: Dr. Viviane Jerez (Museo de Zoología, University of Concepción), Dr. Sergio Letelier (Museo Nacional de Historia Natural, Chile). Furthermore, we thank Lizandro Chuecas for correcting the English text. This reasearch was fully supported by FONDAP-N 3 Oceanography and Marine Biology, "The diversity, biogeography and dynamics of nearshore ecosystems in Chile: foundations for marine conservation ecology". This publication was supported by the Patagonian Ecosystems Research Center (CIEP) of CONICYT.

\section{LITERATURE CITED}

BOWMAN RS (1981) The morphology of Patella spp. juveniles in Britain, and some phylogenetic inferences. Journal of the Marine Biological Association of the United Kingdom 61: 647-666.

BRANCH GM (1975) Ecology of Patella species from the Cape Peninsula, South Africa. IV Desiccation. Marine Biology 32: 179-188. 
BRAY JR \& JT CURTIS (1957) An ordination of the upland forest communities of Southern Wisconsin. Ecological Monographs 27: 325-349.

CASTILLA JC, SA NAVARRETE \& J LUBCHENCO (1993) Southeastern Pacific coastal environments: main features, large-scale perturbations, and global climate change. In: Mooney H, E Fuentes \& B Kronberg (eds) Earth system responses to global change: 167-188. Academic Press, New York, New York, USA.

CERVELLA P, L RAMELLA, CA ROBOTTI \& G SELLA (1988) Chromosome analysis of three species of Patella (Archaeogastropoda). Genetica 77: 97-103.

CHRISTIAENS J (1973) Révision du genre Patella. Informations de la Société Belge de Malacologie (Sér. 2) 9: 153-155

CHRISTIAENS J (1974a) Révision du genre Patella. Bulletin du Muséum National d'Histoire Naturelle (Sér. 3) 182: 1305-1392.

CHRISTIAENS J (1974b) Additifs á la révision du genre Patella. Informations de la Société Belge de Malacologie (Sér. 3) 5: 63-68.

CORTE-REAL HP, SJ HAWKINS \& JP THORPE (1996) An interpretation of the taxonomic relationships between the limpets Patella rustica and P. piperata. Journal of the Marine Biological Association of the United Kingdom 76: 717-732.

CRAME JA (1997) An evolutionary framework for the polar regions. Journal of Biogeography 24: 1-9.

CRETELLA M, G SCILLITANI, F TOSCANO, P TURELLA \& O PICARIELLO (1990) Comparative morphology of soft parts of Patella L., 1758 from the Bay of Naples (Gastropoda: Patellidae). Bolletino Malacologico (Italy) 26: 205-210.

DALL WH (1871) On the limpets; with special reference to the species of the west coast of America, and to a more natural classification of the group. American Journal of Conchology (USA) 6: 227-282.

DELL RK (1964) Marine Mollusca from Macquarie and Heard islands. Records of the Dominion Museum (New Zealand) 4: 267-301.

DELL RK (1971) The marine Mollusca of the Royal Society Expedition to Southern Chile, 1958-59. Records of the Dominion Museum (New Zealand) 7: $155-233$

ESCRIBANO R, M FERNÁNDEZ \& A ARANIS (2003) Physical-chemical proceses and patterns of biodiversity of the Chilean eastern boundary pelagic and bernthic marine ecosystems: a review. Gayana (Chile) 67: 190-205.

FERNÁNDEZ M, E JARAMILLO, P MARQUET, C MORENO, S NAVARRETE, P OJEDA, C VALDOVINOS \& J VÁSQUEZ (2000) Diversity, ecology and biogeography of Chilean benthic nearshore ecosystems: an overview and guidelines for conservation. Revista Chilena de Historia Natural 73: 797-830.

FIELD JG, KR CLARKE \& RM WARWICK (1982) A practical strategy for analysing multispecies distribution patterns. Marine Ecology Progress Series 8: 37-52.

FISCHER-PIETTE E (1935) Systématique et biogéographie - les patelles d'Europe et d'Afrique du Nord. Journal de Conchyliologie 99: 135-200.

FRETTER V \& A GRAHAM (1962) British prosobranch molluscs, their anatomy and ecology. Ray Society, London, United Kingdom. 755 pp.

GARRITY SD (1984) Some adaptations of gastropods to physical stress on a tropical rocky shore. Ecology 65: $559-574$
GOLIKOV AN \& YI STAROBOGATOV (1975) Systematics of prosobranch gastropods. Malacologia 15: 185-232.

HODGSON AN \& RT BERNARD (1989) Spermatozoan structure and the taxonomic affinity of the limpet Nacella delesserti (Gastropoda: Patellidae). Journal of Molluscan Studies 55: 145-147.

KEEN AM (1960) Superfamily Patellacea Rafinesque 1815. Treatise on invertebrate paleontology. In: Moore RC (ed) Mollusca: 1: 231-236. Geological Society of America and University of Kansas Press, Laurence, Kansas, USA.

LINDBERG DR (1981) Acmaeidae. Boxwood Press, California, USA. $122 \mathrm{pp}$.

LINDBERG DR (1988) The Patellogastropoda. Malacological Review Supplement 4: 35-63.

LINDBERG DR (1998) Order Patellogastropoda. In: Beesley PL, GJB Ross \& A Wells (eds) Mollusca: the southern syntesis. Fauna of Australia 5: 639652. CSIRO Publishing, Melbourne, Australia.

LINDBERG DR \& C HEDERGAARD (1996) A deep water patellogastropod from Oligocene waterlogged wood of Washington state, USA (Acmaeoidea: Pectinodonta). Journal of Molluscan Studies 62: 299-314.

LINDBERG DR \& JH MCLEAN (1981) Tropical eastern Pacific limpets of the family Acmaeidae (Mollusca, Archaeogastropoda): generic criteria and descriptions of six new species from the mainland and the Galapagos 1slands. Proceedings of the California Academy of Sciences 42: 323-339.

MAHON AR, CD AMSLER, JB MCCLINTOCK \& BJ BAKER (2002) Chemo-tactile predator avoidance responses of the common antarctic limpet Nacella concinna. Polar Biology 25: 469-473.

MORRICONI E (1999) Reproductive biology of the limpet Nacella (P.) deaurata (Gmelin, 1791) in bahía Lapataia (Beagle Channel). Scientia Marina 63: 417-426.

PECK L S \& R VEAL (2001) Feeding, metabolism and growth in the Antarctic limpet, Nacella concinna (Strebel 1908). Marine Biology 138: 553-560.

PICKARD GL (1971) Some physical oceanographic features of inlets of Chile. Journal of Fisheries Research Board of Canada 28: 1077-1106.

PILSBRY HA (1891) Manual of Conchology 13. Academy of Natural Sciences, Philadelphia, Pennsylvania, USA. 195 pp.

PONDER WF \& R CREESE (1980) A revision of the Australian species of Notoacmea, Collisella and Patelloidea. Journal of the Malacological Society of Australia 4: 167-208.

POWELL AWB (1951) Antarctic and subanctarctic Mollusca: Pelecypoda and Gastropoda. Discovery Reports (USA) 26: 49-196.

POWELL AWB (1973) The patellid limpets of the world (Patellidae). Indo-Pacific Mollusca 3: 75-206.

POWELL DK, PA TYLER \& LS PECK (2001) Effect of sperm concentration and sperm aging on fertilisation success in the Antarctic soft-shelled clam Laternula elliptica and the Antarctic limpet Nacella concinna. Marine Ecology Progress Series 215: 191-200.

REID D \& C OSORIO (2000) The shallow-water marine Mollusca of the Estero Elefantes and Laguna San Rafael, southern Chile. Bulletin of the Natural History Museum of London, Zoology Series 66: 109-146.

RIDGWAY SA, DG REID, JD TAYLOR, GM BRANCH \& AN HODGSON (1998) A cladistic phylogeny of 
the family Patellidae (Mollusca: Gastropoda) Philosophical Transactions of the Royal Society of London B 353: 1645-1671.

SASAKI T \& T OKUTANI (1993a) Anatomy and systematic position of Yayoiacmea, a new genus for japanese tiny limpet "Collisella" oyamai Habe, 1955 (Gastropoda: Lottidae). Venus 52: 193-209.

SASAKI T \& T OKUTANI (1993b) New genus Nipponacmea (Gastropoda, Lottidae): a revision of japanese limpets Hiterto allocated in Notoacmea. Venus 52: 1-40.

SASAKI T \& T OKUTANI (1994a) An analysis on "Collisella heroldi" complex (Gastropoda: Lottidae), with description of three new species. Venus 53: 251-285.

SASAKI T \& T OKUTANI (1994b) Description of a new Lottid Limpet, Nipponacmea habei, with special reference to morphology and distribution of two infraspecific populations. Venus 53: 1-20.

STANWELL-SMITH D \& A CLARKE (1998) The timing of reproduction in the Antarctic limpet Nacella concinna (Strebel, 1908) (Patellidae) at Signy
Island, in relation to environmental variables. Journal Molluscan Studies 64: 123-127.

THIELE J (1929) Handbuch der systematischen Weichtierkunde. Gustav Fischer, Jena 1.

VALDOVINOS C, S NAVARRETE \& P MARQUET (2003) Mollusk species diversity in the southeastern Pacific: why are there more species towards the pole? Ecography 26: 139-144.

VERMEIJ GJ (1973) Morphological patterns in highintertidal gastropods: adaptative strategies and their limitations. Marine Biology 20: 319-346.

VIVIANI CA (1979) Ecogeografía del litoral chileno. Studies on Neotropical Fauna and Environment 14: 65-123.

WALKER CG (1968) Studies on the jaw, digestive system, and coelomic derivates in representatives of the genus Acmaea. Veliger 11: 89-97.

WENZ W (1938) Gastropoda. Allgemeiner: Teil und Prosobranchia. In: Schindewolf $\mathrm{OH}$ (ed) Teil I Band 6: 1-1639. Handbuch der Paläozoologie, Berlin, Germany. 